\title{
MIDWIFERY AND MALPRACTICE INSURANGE: A PROFESSION FIGHTS FOR SURVIVAL
}

\author{
GaIL A. Robinson ${ }^{\dagger}$
}

\begin{abstract}
[Subsequent to the completion of this Comment, the American College of Nurse-Midwives decided to self-insure, ${ }^{*}$ thus adopting the proposal this Comment advocates. Nonetheless, we have decided to publish the Comment because it addresses important legal and social issues.]
\end{abstract}

"MIDWIVES FACING LOSS OF INSURANCE." Similar headlines across the country announce the newest danger threatening both midwives who wish to practice their profession and consumers who seek their services. ${ }^{2}$ In May 1985, the major carrier of malpractice insurance for nurse-midwives decided that it would not renew a blanket policy covering more than fifty percent of the members of the American College of Nurse-Midwives (ACNM). ${ }^{3}$ To date, the ACNM, the na-

† B.A. 1984, Rutgers University; J.D. Candidate 1987, University of Pennsylvania.

* On December 15, 1985, the American College of Nurse Midwives (ACNM) made the following announcement: "The threat of a service interruption by the nation's nurse-midwives will be averted by the establishment of an independent mutual insurance company to be managed specifically on behalf of certified nurse-midwives. . . . The new plan will go into effect next April 1 [1986]." Nurse-Midwives Solve Insurance Crisis, Avert Breakdown in Maternity Services, Press Release of the American College of Nurse Midwives, Dec. 15, 1985 [on file with the University of Pennsylvania Law Review]. Details of the plan are still being worked out by the ACNM. Telephone interview with Karen Ehrnman, Government Relations Coordinator, AGNM (Feb. 6, 1986).

${ }^{1}$ Lawson, Midwives Facing Loss of Insurance, N.Y. Times, June 13, 1985, at C3, col. 1.

2 See Kolbert, Midwives Face Threat of High Insurance Cost, N.Y. Times, Sept. 29, 1985, at A56, col. 1; Quarembo, Insurance Costs Shut Down Birthing Center, Philadelphia Bus. J., Sept. 23-29, 1985, at 1, col. 2; Malpractice and Midwives, Washington Post, July 6, 1985, at A18, col. 1; Waldholz, Group of Midwives May Lose Coverage From Its Insurer, Wall St. J., June 7, 1985, at 11, col. 2.

3 The ACNM, the national organization of nurse-midwives, has a current membership of about 2,500 , which is approximately $85 \%$ of the profession. American College of Nurse-Midwives, Fact Sheet: Nurse-Midwives and the Malpractice Insurance Crisis 1-2 (rev. Oct. 1, 1985) [on file with the University of Pennsylvania Law Review]. It has provided a group insurance policy to its members since the early 1970's. See K. McHugh, Eastern Pennsylvania Chapter, ACNM, Testimony on the Scarcity and High Cost of Insurance Before the Subcomm. on Commerce, Transportation, and Tourism of the House Comm. on Energy and Commerce, 99th Cong., 1st Sess. 5 (Sept. 19, 1985) [unpublished manuscript on file with the University of Pennsylvania Law Review]. 
tional organization of nurse-midwives, has been unable to find a new insurance carrier. Consequently, almost all of these midwives have been left without insurance.

Other nurse-midwives ${ }^{4}$ are also having difficulty obtaining malpractice insurance. Although many are affiliated with hospitals and physicians that provide malpractice coverage, these policies may not shield them from personal liability, thus requiring them to carry their own professional liability insurance. ${ }^{5}$ Furthermore, a number of possible options to the group ACNM plan have been closed off to nursemidwives through the actions of insurers. ${ }^{\circ}$

The insurance problem is not peculiar to midwives, but rather is of concern to the entire medical profession. ${ }^{7}$ That midwifery services are threatened now, however, is particularly ironic, since in the last decade midwives and their supporters have won a number of legal battles that have saved midwives from near extinction. ${ }^{\mathbf{3}}$

4 A distinction must be made between nurse-midwives and lay midwives. The former are educated in both nursing and midwifery and are certified by the ACNM. Lay midwives usually receive little formal training and learn their craft through experience. See K. McHugh, supra note 3, at 3-4. The problem of obtaining affordable malpractice insurance primarily concerns nurse-midwives rather than lay midwives, since the status of lay midwives is less clear, and many are practicing illegally. See infra notes $27 \& 34$.

- See K. McHugh, supra note 3, at 9.

- In states where nurse-midwives practice in conformity with the state nurse practice act, see, e.g., GA. CoDE ANN. § 43-26-32 (1984); TENN. Code ANN. § 63-7-105 (Supp. 1985), the American Nurses Association's (ANA) group insurance policy would have covered nurse-midwives, except that the ANA's insurer wrote in an exclusion for nurse-midwives effective November 1985. The policy held by the Nurses' Association of the American College of Obstetricians and Gynecologists was also changed recently to exclude nurse-midwives. See K. McHugh, supra note 3, at 9-10.

7 For discussions of the malpractice problem facing the medical profession in general, see Defensive Medicine and Medical Malpractice: Hearing Before the Senate Comm. on Labor and Human Resources, 98th Cong., 2d Sess. (1984) [hereinafter cited as Defensive Medicine Hearing]; U.S. Dep't of Health, Educ., \& Welfare, REPORT OF THE SECRETARY's CoMmission on Medical Malpractice (1973) [hereinafter cited as HEW REPORT]; Lehman, The Cost of Doing Business, Boston Globe, Aug. 26, 1985, at 43, col. 2; Gargan, Albany Tackles Thorny Malpractice Insurance Issue, N.Y. Times, June 20, 1985, at B7, col. 1.

Like doctors, most nurse-midwives will not practice without malpractice insurance. Some type of malpractice insurance is carried by $95 \%$ of the members of the ACNM. See K. McHugh, supra note 3 , at 4.

${ }^{8}$ Midwives have been successful in getting relatively favorable licensing laws passed in many states, see infra notes $32-35$ and accompanying text, and have led successful campaigns for approval of payments under Medicaid and for laws in individual states mandating payment for their services, see infra notes 41-43 and accompanying text. In addition, at least one suit has been brought against doctors and a hospital that tried to interfere with midwife services. See Nurse Midwifery Assocs. v. Hibbett, 549 F. Supp. 1185 (M.D. Tenn. 1982). There has also been a congressional hearing on the problems facing midwives trying to establish a practice. See Nurse Midwifery: Consumers' Freedom of Choice: Hearing Before the Subcomm. on Oversight and Investiga- 
Midwives must remain a viable option for two reasons. First, they provide a safe alternative to the medical model of birth, which encourages the use of drugs and technology even for normal births. ${ }^{9}$ Second, they provide prenatal and intrapartum $\operatorname{care}^{10}$ to women who cannot afford the high fees of doctors and hospitals and who, without midwives, might have no care at all. ${ }^{11}$

This Comment explores the malpractice insurance problem currently facing midwives. Part I reviews the history of American midwifery. Part II discusses the benefits of a strong midwifery profession. Part III presents the malpractice problem both in general and as it applies to midwives, analyzing suggested changes to the present insurance system. Finally, Part IV proposes a solution to the midwives' insurance problem.

tions of the House Comm. on Interstate and Foreign Commerce, 96th Cong., 2d Sess. 1 (1980) [hereinafter cited as Nurse-Midwifery Hearing].

- Many commentators claim that the current dependence of the medical profession on drugs and modern technology is both unnecessary and dangerous. See Nurse-Midwifery Hearing, supra note 8, at 91-93 (testimony of C. Arden Miller, M.D., Chairman, Dep't of Maternal and Child Health, University of North Carolina); id. at 94121 (reprinting C. Miller, What Technology Breeds: A Review of Recent U.S. Experience with Caesarean Section (Mar. 20, 1978) (John Sundwall Memorial Lecture, School of Public Health, University of Michigan)); id. at 145-47 (testimony of Judith Rooks, C.N.M., M.S., M.P.H., Former Consultant, Office of Population Affairs, Dep't of Health and Human Services); B. Rothman, In Labor: Women and POWER IN THE BIRTHPLACE 45-47 (1982).

10 Prenatal care is care given to a woman and the fetus during pregnancy, Stedman's Medical Dicrionary 1293 (24th ed. 1966); intrapartum care is care given during labor and delivery, id. at 822 .

11 Midwives generally charge about half the fee of an obstetrician. See Waldholz, supra note 2 , at 11 , col. 2 . In the home-birth situation, hospital fees are eliminated as well.

In addition to charging lower fees, midwives have a history of assisting the poor. One of the first midwifery centers in the United States was the Frontier Nursing Service in Eastern Kentucky, established in 1925. The Service provided health care to a poor, mountainous region of Kentucky and may be credited with significant improvements in health. See C. Miller, What Technology Breeds: A Review of Recent U.S. Experience with Gaesarean Section (Mar. 20, 1978) (John Sundwall Memorial Lecture, School of Public Health, University of Michigan), reprinted in Nurse-Midwifery Hearing, supra note 8, at 94, 114. Midwives' historical concern for the poor continues today. See Spending Reduction Proposals (Part II): Hearings Before the Senate Comm. on Finance, 97th Cong., 1st Sess. 340-42 (1981) (testimony of Sally Tom, G.N.M., Government Liaison, ACNM) (discussing the successful results that midwives have had in poor, rural areas) [hereinafter cited as Spending Reduction Hearings]; Piechnik \& Corbett, Reducing Low Birth Weight Among Socioeconomically High-Risk Adolescent Pregnancies, 30 J. NuRSE-MIDwIFERY 88 (1985) (study showing a significantly lower incidence of low-birth-weight infants of pregnant adolescents under certified nurse-midwife care); Tom, Political Midwifery, 27 J. NuRse-MrdwIFERy 19, 1920 (1982) (discussing the responsibility of nurse-midwives to serve "out-of-power" peoples). 


\section{The History of American Midwifery}

\section{A. From Dominance to Extinction}

The female midwife ${ }^{12}$ was the only accepted birth attendant for centuries. ${ }^{13}$ The birth process was thought to be the sole province of the female. It was not until the middle of the eighteenth century that men in the American colonies became involved in the process. ${ }^{14}$ Once male doctors realized the economic and professional advantages of dominating the birth field, however, they worked hard to convince women that the only safe means of giving birth was with an attendant physician. ${ }^{18}$

This monopolization campaign took several forms. The American Medical Association (AMA) was founded as a vehicle to promote the economic and social advancement of medicine. ${ }^{16}$ It was highly successful in getting restrictive licensing laws passed that helped secure the exclusive right of doctors to practice medicine. ${ }^{17}$ Once assisting with

22 A midwife is defined as "a woman who assists women in childbirth." RaNDOM House DictionaRy of THE ENGLISH LANGUAGe 908 (unabridged ed. 1983).

13 See J. Donegan, Women and Men Midwives: Medicine, Morality and Misogyny in EARLy AMERICA 9-33 (1978) (discussing the origins of midwifery in England). For additional history on English midwifery and the influence of technology on the birth process, see generally A. OAKLEY, The CAPTUREd WOMB: A History of the Medical Gare of Pregnant Women (1984). For a study of childbirth in traditional tribal cultures, see generally J. GoldsMITH, CHILdBIRTH Wisdom (1984). Goldsmith suggests that Westerners, who often view birth as a pathological occurrence-a disease rather than a natural process-can learn a considerable amount from the tribal cultures' attitude toward birth. See id. at 182-87.

14 See M. Edwards \& M. Waldorf, Reclaiming Birth: History and HerOINES OF AMERICAN CHILDBIRTH REFORM 149 (1984). One of the major reasons that men began to dominate the birth process was the introduction of the use of forceps to assist in birth. These new instruments were given much credit for easing the difficulties of birth, but they remained almost exclusively in the hands of male doctors and surgeons. Female midwives were given neither the instruction in the use of forceps nor the training in anatomy and surgery that was necessary to utilize the instruments correctly. See id.; see also W. ARNey, PoWer and the Profession of OBstetrics 47 (1982) ("[T]he 'prophylactic forceps operation' . . . obliterated the boundary between normal and abnormal and allowed male midwives to take over, conceptually and instrumentally, the domain of the midwife.") (citation omitted); J. DonEGaN, supra note 13, at 59 (discussing the surgeons' exclusive use of the forceps as a means of maintaining a superior status).

${ }_{15}$ See W. ARNEY, supra note 14, at 42-47 (suggesting that doctors gained control over the birth process by creating a pathological theory of pregnancy and fostering an image of obstetrics as a complicated specialty); M. EDWARDS \& M. WALDORF, supra note 14, at 151-57 (discussing the societal changes that led to the use of male birth attendants).

${ }^{16}$ See M. EdWARdS \& M. WALdorf, supra note 14, at 151.

${ }^{37}$ See id. at 151. For examples of current licensing laws, see CAL. Bus. \& Prof. CODE $\S 2052$ (West Supp. 1986) (prohibiting treatment or diagnosis by uncertified practitioners); Colo. REV. STAT. § 12-36-106(2) (1978) (requiring a license to practice medicine); N.J. Stat. ANN. § 45:9-6 (West 1978 \& Supp. 1985) (requiring a license to practice medicine or surgery); PA. Stat. AnN. tit. 63, $\S 421.3$ (Purdon 
birth was viewed as practicing medicine, midwives, by virtue of the licensing laws, were excluded from this role.

Industrialization, by reducing the need for women's domestic labor, also assisted physicians in their quest for dominance:

Working-class women left home often to work in factories and mills, while middle and upper-class women were left without any vital function except that of bearing children. Under enforced leisure and tightly-laced, unhealthy fashions . . . women of privilege slipped into chronic invalidism, requiring frequent medical visits. ${ }^{18}$

The need for frequent care created yet another opportunity for male doctors to convince women that they were dependent upon the medical profession and that it alone could offer relief from the danger and pain of childbirth. By the 1930's physicians had succeeded in persuading women to use only medically trained physicians as birth attendants, thereby causing midwives to appear as a wholly inferior choice, used only by those too poor or too ignorant to get a doctor. ${ }^{18}$

Consistent with the physicians' position that women were dependent on male birth attendants for a successful birth, the medical model views normal birth as a pathological occurrence that necessitates medical interference. Under this model, the doctor delivers the baby, and the mother is merely the receptacle from which it emerges. ${ }^{20}$

The first stirrings against this medical monopoly and the model of birth it represented came in the 1950's with the Lamaze technique of "painless childbirth." Women who before had been in a state of "twilight sleep"22 during birth were now encouraged to remain awake and

Supp. 1985) (prohibiting the unlicensed practice of medicine and surgery).

18 M. EDWARDS \& M. WALDORF, supra note 14, at 152.

19 Midwives were a special target for elimination by doctors. When high infant mortality rates in turn-of-the-century New York were made public, doctors blamed midwives. A 1910 national survey funded with Carnegie money recommended that a campaign to drive midwives out of the maternity field be mounted. Efforts such as these were successful in lowering the number of midwife-attended births in New York City from two-fifths of all births in 1900 to one-tenth by 1932 . This phenomenon was by no means limited to New York. Midwife deliveries across the country dropped from 50\% in 1900 to $12 \%$ in 1936. See M. EDWARDS \& M. WALDORF, supra note 14, at 153. $33-40$

${ }^{20}$ See infra notes 44-47 and accompanying text; B. RoTHMAN, supra note 9, at

${ }^{21}$ Lamaze's method of "childbirth without pain" involved a series of physical and mental exercises designed to change a woman's perception of pain. The newly conditioned reflexes developed by these exercises were to replace the signal of pain with the signal of the work of producing a child, thereby carrying the woman through labor awake and in control of her own body. See M. EDWARDS \& M. WALDORF, supra note 14 , at 42-48; B. Rothman, supra note 9, at 30-31.

${ }_{22}$ Twilight sleep is a state of semiconsciousness induced by drugs. It does not 
"help" their doctors with the delivery. ${ }^{23}$ Although movements like Lamaze took a few steps away from the medical model, they were by no means a revolution. Women about to give birth continued to be strapped to tables with their legs in stirrups, and the technology of childbirth grew more complex and was more routinely employed. ${ }^{24}$

Spurred by increasing self-awareness, ${ }^{25}$ women responded to this overabundance of technology by searching for a method of childbirth that was less male-dominated and that treated birth as a natural process. ${ }^{26}$ Midwives once more began to be an attractive choice as a birth attendant; however, they were few in number and sometimes impossible to engage because of unfavorable state licensing laws ${ }^{27}$ and fierce opposition from the medical profession..$^{28}$ Both midwives and consumers had

eliminate pain but is supposed to separate the woman from the experience of birth so that she will not remember the pain. See B. Rothman, supra note 9, at 59. For a history of the twilight sleep method, see M. Sandelowski, Pain, Pleasure and american Childbirth: From the Twilight Sleep to the Read Method, 1914-1960, at 3-20 (1984).

${ }^{23}$ See B. Rothman, supra note 9, at 30-31.

24 The use of fetal monitoring, introduced into clinical obstetrics in 1969 , is now routine. It was used in $70 \%$ of all births in 1978. See $1 \mathrm{~S}$. Pegalis \& H. Wachsman, American LAW of Medical Malpractice $\S 4: 26$, at 366 (1980). There are three methods of fetal monitoring: externally by ultrasound monitoring of the fetal heart rate and uterine contractions; internally by a fetal electrocardiogram that is obtained by attaching electrodes to the baby's head and by uterine monitoring using a catheter passed into the uterus through the cervix; and internally by direct sampling of fetal blood, which is obtained by screwing an electrode into the baby's head. See B. RoTHMAN, supra note 9 , at 45 . All of these methods necessarily constrict the mother's movement during the birth, thereby affecting the position she many assume and preventing her from walking or squatting if that is more comfortable. Moreover, both internal methods require artificial rupture of the amniotic membrane. In addition, the increased use of fetal monitoring is associated with a higher rate of caesarean section. See C. Miller, supra note 11 , at 104-05.

${ }^{25}$ The women's health movement has caused the female patient to accept responsibility for her own health and reject the often dominating relationship of the doctor over the patient. See C. Miller, supra note 11, at 118-19.

${ }^{28}$ See infra text accompanying notes 48-52.

${ }^{27}$ In California, for instance, lay midwives still may not practice legally. There is no state law providing for their licensing, and the California Supreme Court has held that the practice of lay midwifery violates a provision of California law, currently set forth at GAL. BuS. \& PROF. Code $\S 2052$ (West Supp. 1986), that prohibits the unlicensed practice of medicine. See Bowland v. Municipal Court, $18 \mathrm{Cal}$. 3d 479, 556 P.2d 1081, 134 Cal. Rptr. 630 (1976); see also M. EDWARDS \& M. WALDORF, supra note 14, at 164-79 (catalogue of midwife arrests in California from 1974 to 1982); Caldwell, Bowland v. Municipal Court Revisited: A Defense Perspective on Unlicensed Midwife Practice in California, 15 PAC. L.J. 19 (1983) (suggesting that Bowland be reexamined in light of recent changes in California right-to-privacy law).

${ }^{28}$ See, e.g., Nurse Midwifery Assocs. v. Hibbett, 549 F. Supp. 1185 (M.D. Tenn. 1982) (refusing to grant defendants' motion to dismiss an antitrust suit brought by two nurse-midwives and their backup physician against a hospital for denying the midwives staff privileges and against an insurance company owned and operated by doctors for refusing to renew the malpractice insurance of the backup physician); Note, Hospital Privileges for Nurse-Midwives: An Examination Under Anti-trust Law, 33 AM. U.L. 
to fight to make midwifery a viable option again.

\section{B. The Legal Battles}

Three main obstacles stood in the path of a midwifery revival: first, the total absence of state licensing laws and the existence of hostile laws inhibiting the practice of midwifery; ${ }^{29}$ second, institutional obstacles imposed by hospitals that refused to grant staff privileges to midwives and by doctors who refused to provide the necessary backup services; ${ }^{30}$ and third, the refusal of insurance companies to reimburse policyholders for midwife services. ${ }^{31}$ Midwives have been fairly successful in overcoming these problems.

Although some state laws are more favorable than others, ${ }^{32}$ nurse-

REv. 959 (1984) (examining the denial of hospital privileges to nurse-midwives under antitrust law); deCourcy Hinds, Midwives Seek Delivery From Discrimination, N.Y. Times, Aug. 7, 1983, $\S 4$, at E9, col. 1 (discussing the barriers faced by midwives seeking to operate independently of physicians).

29 See, e.g., supra note 27.

so See Nurse-Midwifery Hearing, supra note 8, at 20-21 (testimony of Judy Norsigian, Action Vice-Chair, National Women's Health Network) (discussing midwives in Arkansas who were unable to obtain a backup physician and midwives in Connecticut who were refused hospital privileges); id. at 35-45 (testimony of William Martin, M.D.) (describing events leading up to the litigation in Nurse Midwifery Assocs. v. Hibbett, 549 F. Supp. 1185 (M.D. Tenn. 1982)); id. at 55-59 (testimony of Lonnie Morris, C.N.M., M.S., Childbirth Center, Englewood, N.J.) (describing physician resistance in New Jersey, where the board of medical examiners, encouraged by local physicians, attempted to promulgate extremely restrictive regulations governing midwives).

${ }_{31}$ Direct insurance reimbursement, in which either the nurse-midwife is paid directly by the insurer or the patient is reimbursed for the cost of midwife services, is an important issue for midwives because it is a means to economic independence from physicians and can affect whether a patient will go to a midwife at all. See Cohn, Survey of Legislation on Third Party Reimbursement for Nurses, 11 LAw, MED. \& Health Care 260, 260-63 (1983).

${ }^{32}$ For example, in Idaho the relationship between the nurse-midwife and her backup physician is monitored in detail. The midwife must submit a description of the scope of her practice and a copy of her agreement with the "supervising" physician. There must be regularly. scheduled conferences between the physician and the midwife as well. Perhaps as a result of this restrictive supervision, there were fewer than 10 nurse-midwives practicing in Idaho as of November 1983. See Cohn, Cudding, Kraus \& Tom, Legislation and Nurse-Midwifery Practice in the USA: Report on a 1983 Survey Conducted by the Political and Economic Affairs Committee of the American College of Nurse Midwives, 29 J. NuRSE-MidwIFERY 55, 87 (1984). In contrast, as the result of a court decision, nurse-midwives in Missouri can practice without direct physician supervision. See Sermchief v. Gonzales, 660 S.W.2d 683, 689-90 (Mo. 1983) (holding that services routinely provided by nurses and done pursuant to written protocols signed by a physician were within the "profession of nursing" standard provided by statute and did not constitute the unlawful practice of medicine).

The vehicle through which a state supervises midwives can be either hostile or favorable. For example, North Carolina regulates midwives through a midwifery committee that has representatives of midwives as well as physicians and administrators. See Cohn, Cudding, Kraus \& Tom, supra, at 129. This gives midwives some control 
midwifery practice is now legal in almost every state. ${ }^{3 s}$ The status of lay midwives is less certain, but they are able to practice legally in some states. ${ }^{34}$ Midwives have strongly advocated favorable licensing laws and view such laws as a way of establishing midwifery as an independent profession. ${ }^{35}$

Nurse-midwives have slowly gained the cooperation of the medical profession, ${ }^{36}$ but relations between the two groups are far from smooth. Many obstetricians see midwives as an economic threat to their prac-

over their own profession rather than placing them under the sole supervision of the state medical board, whose members may have a bias toward physicians. The situation in Ohio is a good example of the effect that such medical board supervision can have. The procedure for receiving authorization to practice as a midwife in Ohio, though described fairly simply in the authorizing statute itself, has become complex, and it may take several months to complete. See id. at 133; see also Comment, Senate Bill 204: Back to Basics in "Birthing," 14 CAP. U.L. REv. 103, 110-11 (1984) (stating that an Ohio statute that does not expressly grant or deny hospital privileges to midwives has allowed hospital boards to conclude that midwives were not granted these privileges); Comment, A Matter of the Quality of Birth: Mothers and Midwives Shackled by the Medical Establishment and Pennsylvania Law, 23 DuQ. L. Rev. 171, 189-90 (1984) (stating that Pennsylvania law on the practice of midwifery-which limits practice to those properly certified in accordance with the regulations promulgated by the State Board of Medical Education and Licensure, a body primarily composed of physicians-has reduced the number of practicing midwives).

ss See Cohn, Cudding, Kraus \& Tom, supra note 32, at 55-174 (listing the legal status of nurse-midwives in every U.S. jurisdiction). The states of Nebraska and North Dakota, however, still do not provide clear statutory authority for nurse-midwife practice. See id. at 60 .

st Unlike the California courts, the Texas courts have separated midwifery from the practice of medicine. According to the Texas courts, lay midwifery does not constitute the illegal practice of medicine, and therefore lay midwives are free to assist births despite the absence of a specific authorizing statute. See Banti v. State, 163 Tex. Crim. 89, 289 S.W.2d 244 (1956); see also R. DeVries, Regulating Birth: Midwives, MEDICINE \& THE LAW 61-70 (1985) (survey of recent legislative attempts in Texas to regulate the practice of lay midwifery).

Lay midwives may practice legally in Arizona, but they must fulfill certain educational and practice requirements and pass a qualifying exam. See id. at 55-61; see also Weitz \& Sullivan, Licensed Lay Midwifery in Arizona, 29 J. NuRSE-MIDWIFERY 21, 22 (1984) (State regulations require that lay midwives undertake certain training and pass written, oral, and clinical examinations with a minimum score of $80 \%$ correct.).

ss See Rothman, Childbirth Management and Medical Monopoly: Midwifery as (almost) a Profession, 29 J. NuRSE-MidwIFERY 300, 306 (1984) (stating that a profession has ultimate control over its work and the knowledge associated with it, and that professional status comes from political action). But see R. DEVRIEs, supra note 34 , at 116-17. DeVries argues that licensing has forced midwives who practice legally to do so under more restrictions than midwives practicing illegally, where patient and midwife are "co-conspirators" and have the freedom of not being bound by external rules. Nonetheless, DeVries recognizes that midwives practicing illegally pay a price for this freedom, including fear of being sued, inability to advertise, and inability to accompany their patients to the hospital.

so Nurse-midwives are viewed more favorably than lay midwives by the medical profession "because they are drawn from the ranks of nurses, an ancillary medical occupation." R. DEVRIEs, supra note 34 , at 115 . Lay midwives enjoy no such recognition from doctors. See id. at 60, 115-16. 
tices and do all in their power to impede the practice of midwifery. ${ }^{37}$ Hostility between midwives and physicians has existed throughout history; ${ }^{38}$ although there has been some reconciliation, midwives will likely have to continue to fight at least some physicians to retain their current status.

The successful battle to obtain insurance reimbursement for midwife services has been a major factor in allowing midwives to establish practices outside of hospitals and independent of doctors. Midwives do not practice with complete independence; they always have a backup physician for emergencies and send any women whose pregnancy may be complicated to a doctor. ${ }^{39}$ Nonetheless, before reimbursement was possible they could not get paid without the cooperation of their backup physicians and therefore could not engage in an economically independent practice. ${ }^{40}$

Several states have recently passed laws mandating reimbursement for midwife services. ${ }^{41}$ The federal government provides reimbursement

37 See Nurse-Midwifery Hearing, supra note 8, at 72-76 (testimony of Ruth Lubic, C.N.M.) (describing the obstacles that the local medical profession placed in the path of establishing a free-standing birth center in New York City); id. at 164 (statement of the American College of Obstetricians and Gynecologists) (describing the call for alternative health care in the field as "an attempt to re-order the practice of medicine ... increasing the risk to the patient by permitting less than adequately trained individuals to independently manage and direct . . . care").

ss See supra notes 15-28 and accompanying text.

so See Spending Reduction Hearings, supra note 11, at 340 (testimony of Sally Tom, C.N.M., Government Liaison, ACNM) ("Nurse-midwives screen carefully for indications of medical problems and collaborate closely with physicians when complications arise, thus identifying clients who are essentially medically normal . . . ."); ACNM \& American College of Obstetricians and Gynecologists, Joint Statement of Practice Relationships Between Obstetricians/Gynecologists and Certified Nurse-Midwives (Nov. 1, 1982) [on file with the University of Pennsylvania Law Review]; K. McHugh, supra note 3, at 3-4.

10 See Spending Reduction Hearings, supra note 11, at 346-47 (testimony of Sally Tom, C.N.M., Government Liaison, ACNM) (stating that nurse-midwives will always collaborate closely with physicians but that the employment relationship between a midwife and her backup physician cannot remain that of an employee and her employer if midwives are ever to become economically independent).

11 Sixteen states now provide for direct reimbursement by insurers for the services of nurses, and hence, for the services of nurse-midwives. See ALASKa STAT. $\S 21.42 .355$ (Supp. 1983); ConN. Gen. Stat. AnN. § 38-174v (West Supp. 1985); Mo. AnN. Code art. 48A, § 354N (1983); MinN. Stat. ANN. § 62a.15(3a) (West Supp. 1985); MIss. CODE ANN. § 83-41-213 (Supp. 1984) (reimbursement for services of a "duly certified nurse practitioner working under the supervision of a duly licensed physician"); MONT. CODE ANN. § 33-22-111 (1985); N.J. STAT. ANN. § 17B:26-40 (West 1985); N.M. Stat. ANn. § 59A-47-28.1 (Supp. 1985); N.Y. Ins. LAW $\S 3216(10)$ (a) (McKinney Supp. 1985); Omo Rev. CoDE ANN. \& 3923.23.3 (Page Supp. 1984); Or. Rev. Stat. § 743.128 (Supp. 1985); PA. Stat. ANN. tit. 40, $\S 3002$ (Purdon Supp. 1985); S.D. Codified LAws ANN. § 58-17-54 (Supp. 1985); UTAH CODE ANN. § 31-33-2(4) (Supp. 1985) (not specifically mentioning nurse-midwives but ensuring reimbursement for any "practitioner of the healing arts"); WASH. 
through Medicaid ${ }^{42}$ and the Civilian Health and Medical Program of the Uniformed Services (CHAMPUS). ${ }^{43}$ These developments have gone a long way in allowing midwives a measure of independence not previously possible.

\section{The Benefits of a Strong Profession of Midwifery}

There are two main reasons why the presence of a strong profession of midwifery is desirable. First, midwifery affords a choice to women seeking an alternative to the medical model of birth. Second, midwives provide services for the poor who might otherwise be forced to go without prenatal and intrapartum care.

\section{A. The Psychology of Midwifery}

There are considerable differences between the medical model of birth and the model endorsed by midwives. The medical profession tends to characterize the normal birth process as pathological and, therefore, as requiring medical intervention. ${ }^{44}$ The medical profession thus refers to the birth process as delivery by doctors rather than the giving of birth by mothers, ${ }^{45}$ and routinely relies on elements alien to the natural birth process, such as drugs, episiotomies, ${ }^{46}$ fetal monitoring, and caesarean sections. ${ }^{47}$

Rev. Code AnN. $\S 48.44 .290$ (West 1984); W. VA. Code $\S 33-15-4 b$ (Supp. 1985). 42 See 42 U.S.C. $\$ 1396 \mathrm{~d}(\mathrm{a})(17)$ (1982).

4s 10 U.S.C.A. \& 1079(a)(13) (West Supp. 1985) (permitting reimbursement for midwife services utilized by dependents of members of the uniformed services).

44 See W. ARNEY, supra note 14, at 42-45. Arney argues that obstetricians created a pathological theory of pregnancy in order to establish dominance over the midwifery profession. By convincing women that pregnancy was a "disease," they could put themselves forth as the only sound way to affect a "cure." Id.; see also B. RothMAN, supra note 9, at 23-24, 33-41. Rothman describes the medical model as one in which "the body is seen as a machine, and the male body is taken as the norm. Pregnancy and birth are at best complications . . . [and at] worst . . . diseaselike states." Id. at 24 .

45 See B. Rothman, supra note 9, at 61-62.

46 An episiotomy is a surgical incision into the perineum and vagina for obstetrical purposes. Dorland's Illustrated Medical Dictionary 454 (26th ed. 1981). Although many physicians prefer the clean cut of the episiotomy to the jagged tear that may be caused by the baby's head as it emerges, much of this tearing occurs because of the insistence of these physicians on using the American style of delivery. B. RothMAN, supra note 9, at 58. A supine position, with the legs in stirrups, is not the position most conducive to birth without tearing. See id.; see also Formato, Routine Prophylactic Episiotomy: Is It Always Necessary?, $30 \mathrm{~J}$. NuRSE-MIDwIFERY 144, 145-46 (1985).

17 Fetal monitoring was used in $70 \%$ of all births in 1978. See $1 \mathrm{~S}$. PEgalis \& H. WACHSMAN, supra note $24, \S 4.26$, at 366 . The use of fetal monitoring is often associated with higher caesarean section rates. See C. Miller, supra note 11, at 104-05. The caesarean rate in the United States tripled between 1971 and 1981 and now approaches 
In contrast, the midwife views birth as a natural process and her role as merely an attendant, present to assist the mother as she gives birth to the baby. ${ }^{48}$ Resort to drugs, modern technology, and other interventionist techniques for normal deliveries is much rarer among midwives than it is among their medical counterparts. ${ }^{49}$ Midwives believe in assisting the birth process through natural means, and for the most part they allow nature to take its course. ${ }^{50}$ They view birth as a family event, and many encourage a woman to have her family and friends with her during the birth. ${ }^{51}$ Because of their perspective, midwives provide a quality of care in terms of nurturing and psychological support that is often lacking in the typical doctor-patient relationship. ${ }^{\mathbf{} 2}$

Of course, midwives are not the right choice for all women. They provide proper care only for "low risk" women: those whose medical history and present condition suggest that there will be no complications during the pregnancy or birth. ${ }^{6 s}$ Women who have such complica-

$20 \%$ of all deliveries nationwide. See id. at 98, 102; Defensive Medicine Hearing, supra note 7, at 234-36 (statement of Esther Zorn, Founder/President, Cesarean Prevention Movement, Inc.).

18 See B. Rothman, supra note 9, at 179-81. "[Midwives] believe[ ] that women's bodies are meant to bear children . . . [and] when . .. [they] do ... [they] are no more 'stressing' the system than ... when ... [they] are digesting a nutritious meal." Id. at 24; see also Beal, Nurse-Midwife Intrapartum Management, $29 \mathrm{~J}$. NURSE-MIDWIFERY 13, 13 (1984) (stating that nurse-midwives view birth as a normal process).

19 See Beal, supra note 48, at 15-17 (concluding, based on a study of medical charts for maternity care at a clinic, that births attended by nurse-midwives entailed a more selective use of IV's, fetal monitoring, pain medication, and anesthesia than physician-attended births). Whereas physicians will be quick to induce late or prolonged labor through the use of drugs or by rupturing membranes artificially, midwives see these two procedures as potentially dangerous. They will more often suggest techniques such as nipple stimulation, sexual intercourse in a comfortable position, or castor oil. See B. Rothman, supra note 9, at 257-58; Davis, The Use of Castor Oil to Stimulate Labor in Patients with Premature Rupture of Membranes, 29 J. NURSE-MIDWIFERX 366 (1984).

${ }^{50}$ The reader should keep in mind that it is only with respect to normal births that midwives oppose the use of drugs and sophisticated technology. They have no dispute with their use in pregnancies that are complicated by other conditions.

51 For a description of a home birth and the atmosphere that midwives encourage, see Nurse-Midwifery Hearing, supra note 8, at 64-69 (statement of Marion McCartney, R.N., C.N.M., Maternity Associates of Bethesda, Md.); B. RotrmaN, supra note 9 , at 287-92.

\$2 Some commentators suggest that this deficiency in the doctor-patient relationship is one cause of the increase in malpractice suits. See REPORT OF THE NEw YORK Special Advisory Panel on Medical Malpractice 86 (1976) [hereinafter cited as New York Report]; J. King, The Law of Medical Malpractice 322-23 (1977); Perlis \& Brucker, Malpractice: A Professional Risk, J. Nurse-MidwiferY, Mar.-Apr. 1983, at 3, 3.

ss "Nurse-midwifery practice is the independent management of care of essentially normal newborns and women, antepartally, intrapartally, postpartally and/or gynecologically." Nurse-Midwifery Hearing, supra note 8, at 7 (testimony of Sally 
tions are referred to doctors. ${ }^{54}$

\section{B. Economics}

Midwives are not only a desirable alternative for those women who can afford traditional medical services but choose the philosophy and experience of a midwife-attended birth, but also a necessity for many poor women who may receive no prenatal or intrapartum care if midwifery services are not available. ${ }^{55}$ The infant mortality rate of children born into low-income families remains considerably higher than that of other children. ${ }^{58}$ One of the major causes of this gap is the high incidence of low-birth-weight babies in the low-income population. ${ }^{57}$ Proper prenatal care can dramatically decrease the number of lowbirth-weight babies. ${ }^{58}$ Midwives can provide this care very effectively.

Several studies and experimental programs have demonstrated the positive effect of introducing midwife care in poor, high-risk populations. ${ }^{59}$ Midwives provide extensive prenatal care, in which they concentrate on proper nutrition and instruct women on how to care for themselves during pregnancy. ${ }^{60}$ Of course, physicians provide excellent prenatal care as well, but their high fees and traditional unwillingness to work in low-income areas make them less available than midwives,

Tom, C.N.M., Government Liaison, ACNM).

st See supra note 39 and accompanying text.

so See supra note 11 and accompanying text.

${ }^{86}$ Statistics show that black infants born into low-income families are twice as likely to die before their first birthday as are white infants born into higher-income families. See Infant Mortality Rates: Failure to Close the Black-White Gap: Hearing Before the Subcomm. on Oversight and Investigations and the Subcomm. on Health and the Environment of the House Comm. on Energy and Commerce, 98th Cong., 2d Sess. 15 (1984) (testimony of Rep. Julian Dixon) [hereinafter cited as Infant Mortality Rate Hearing].

${ }^{57}$ Id. at 33-35 (Two-thirds of all infant mortality is related to the problem of low birth weight.) (testimony of Jeffrey Taylor, Ph.D., Chief, Division of Maternal and Child Health, Michigan Dep't of Public Health).

${ }^{58}$ Id. at 346-48 (testimony of Sally Tom, C.N.M., Government Liaison, ACNM). For example, a study conducted at the Medical University of South Carolina found a birth rate of $9.1 \%$ for those receiving prenatal care as compared with a rate of $12.7 \%$ for those not receiving such care. Id. at 347. Furthermore, women who liked their care-provider expressed more satisfaction with their care and were more likely to keep prenatal appointments. Id. at 346-47.

See Spending Reduction Hearings, supra note 11, at 340-42 (testimony of Sally Tom, C.N.M., Government Liaison, ACNM). For example, in the 18 months following the introduction of a pilot nurse-midwifery project in Madera County, California, the prematurity rate dropped from $11 \%$ to $6.6 \%$; in Holmes County, Mississippi, infant mortality rates dropped from approximately 39 per 1000 live births to 20 per 1000 in the two years following the introduction of nurse-midwife services. $I d$. at 341.

Bo See Infant Mortality Rate Hearing, supra note 56, at 346-48 (testimony of Sally Tom, C.N.M., Government Liaison, ACNM). 
whose fees and operating costs are lower and who historically have been willing to work with the poor. ${ }^{61}$

Midwives' relatively low-cost services also have a beneficial effect on health care costs as a whole. Since midwife-attended births often involve little or no time in the hospital, less expensive technology during the birth, and lower fees for professional services, they lessen the cost of birth not only for the consumer, but for members of group insurance plans and for the taxpayer as well. ${ }^{62}$ The benefit to a society increasingly concerned with the mounting cost of its health care system is obvious. The federal government has recognized the social and economic benefits of midwives and has passed laws acknowledging these advantages. ${ }^{63}$

\section{Safety}

A skeptic may think that midwives should not be trusted with the important task of bringing mothers and babies through the birth process successfully; this conclusion, however, would be wrong. Midwives have been closely monitored, mainly in an effort to discredit them, and studies show that a midwife-attended birth is as safe as one attended by a physician. ${ }^{64}$

61 "The real loss . . . is that nurse-midwives across the country are largely caring for the poor. Obstetricians won't be picking up the care of those patients. "'Lawson, supra note 1, at C3, col. 2 (quoting Edith Wonnell, Director, Birthing Center of Delaware); see also supra note 11 and accompanying text.

${ }^{62}$ Midwives typically earn salaries of $\$ 20,000$ to $\$ 25,000$ per year, and the cost of giving birth in a birthing center is about $\$ 1,500$. The same hospital care costs approximately $\$ 3,000$. See Quarembo, supra note 2, at 62 , col. 1 . Moreover, since midwives utilize drugs and expensive medical technology less often, they save society the cost of the equipment and the personnel needed to administer them. See Beal, supra note 48, at 17. The taxpayer also benefits from the lower cost of midwifery care. Statistics from 1980 show that Medicaid paid from $\$ 1,649.53$ to $\$ 2,230.04$ for normal maternity care with a three-day hospital stay. These figures were approximately $\$ 700$ to $\$ 1,200$ more than the $\$ 1,000$ cost incurred at a birthing center staffed by nurse-midwives. See Nurse-Midwifery Hearing, supra note 8, at 75 (testimony of Ruth Lubic, G.N.M.).

63 Along with reimbursement under Medicaid and CHAMPUS, see supra notes 42-43 and accompanying text, the federal government also encourages nurse-midwifery through grants for training programs. See 42 U.S.C. $§ 297$ (1982). Several federal agencies, including the Indian Health Service and the National Health Service Corps, rely heavily on nurse-midwives to provide care in their programs. See Spending Reduction Hearings, supra note 11 , at 339 (statement of the ACNM).

See Nurse-Midwifery Hearing, supra note 8, at 147 (testimony of Judith Rooks, C.N.M., M.S., M.P.H., former consultant, Office of Population Affairs, Dep't of Health and Human Services) (stating that there are between 30 and 50 published studies about the safety of births attended by nurse-midwives and that "[a]lthough each of these studies is imperfect and inadequate by itself, they accumulate to show a clear trend. In every case, nurse-midwifery service outcomes have been as good, if not better, than what they replaced."). 
It must be remembered that midwives serve only low-risk women who have been carefully screened. ${ }^{65}$ Many midwife-attended births, moreover, occur in a non-hospital setting-the woman's home or a birth center. Moving the birth away from the hospital setting, particularly to the home, greatly decreases the risk of infection to both mother and child..$^{68}$

The tendency of midwives to avoid excessive use of medical technology and drugs adds to their safety record. ${ }^{67}$ Use of unnecessary drugs during birth endangers both mother and child. ${ }^{68}$ The routine use of fetal monitoring for normal births, which is associated with an increase in the caesarean rate, adds to the risks associated with hospital births. ${ }^{69}$ Unless a birth involves medical complications, it is safer to give birth naturally than to undergo unnecessarily the risks of anesthesia and infection that accompany any caesarean section. ${ }^{70}$

Finally, the attitude toward birth taken by midwives adds to the psychological health of both mother and child. The hospital practice of separating mother and infant immediately following birth disrupts the

65 See supra note 39 and accompanying text.

68 In one study comparing home and hospital births of women matched for age, parity (prior birth experience), socioeconomic status, and risk factors, four times as many babies born in the hospital became infected. See B. Rothman, supra note 9, at 43-44.

67 Physicians have been accused of employing drugs and medical technology routinely in normal births. The medical profession has become so dependent on the fruits of its own scientific advancement that it tends to use these devices not because they are medically necessary but because they are part of standard procedure. See supra notes 44-47 and accompanying text; see also Nurse-Midwifery Hearing, supra note 8, at 91112 (testimony of C. Arden Miller, M.D., Chair., Dep't of Maternal and Child Health, University of North Carolina) (arguing that much of this technology has been scrutinized and tested less rigorously than midwives have been).

${ }^{68}$ See, e.g., Haire, Effect of Drugs: How the FDA Determines the Safety of Drugs, J. NuRSE-MIDWIFERY, Mar.-Apr. 1982, at 28. Haire notes that a drug continually or frequently administered to the mother during labor can accumulate in the baby's blood and be trapped there when the umbilical cord is cut. See id. at 30.

60 Women who undergo a caesarean section have a higher mortality rate than those who give birth vaginally. See Nurse-Midwifery Hearing, supra note 8, at 92 (testimony of C. Arden Miller, M.D., Chair., Dep't of Maternal and Child Health, University of North Garolina). Critics have suggested that the caesarean rate in this country is considerably higher than it would be if only medically necessary caesareans were performed. The national rate currently approaches $20 \%$. If only medically necessary caesareans were performed, the rate would be closer to $5 \%$. See Defensive Medicine Hearing, supra note 7, at 234 (statement of Esther Zorn, Founder/President, Cesarean Prevention Movement, Inc.); see also Nurse-Midwifery Hearing, supra note 8, at 91-93 (testimony of C. Arden Miller, M.D., Chair., Dep't of Maternal and Child Health, University of North Carolina).

${ }^{70}$ Fifty percent of women who have caesarean sections are given deep anesthesia and $10 \%$ receive blood transfusions. Both of these procedures carry risks. See NurseMidwifery Hearing, supra note 8, at 92 (testimony of G. Arden Miller, M.D., Chair., Dep't of Maternal and Child Health, University of North Carolina). 
natural bonding process so important to both of them. ${ }^{71}$ In contrast, mother and child are kept together after most midwife-attended births. ${ }^{72}$

Midwives are therefore a desirable alternative to the services offered by the medical profession. If they are to continue practicing, however, a solution must be found to the malpractice insurance crisis they are currently facing.

\section{The Malpractice Grisis}

\section{A. The General Problem}

The problem of obtaining affordable malpractice insurance is neither new ${ }^{73}$ nor confined to midwives. ${ }^{74}$ Nevertheless, it is somewhat ironic that midwives have become one of the hardest-hit victims of the insurance crunch, because proportionately they are sued far less often than physicians. Six percent of the country's midwives have been named in malpractice suits, while sixty percent of obstetricians have been sued for malpractice. ${ }^{75}$

71 See B. Rothman, supra note 9, at 182-84. Rothman notes that medicine has separated the mother from her infant both physically and conceptually. This separation is reflected in the existence of specialties in obstetrics, pediatrics, and neonatology. Id. at 182.

72 Midwives believe that it is important for the mother and child to get to know each other as soon as possible after birth. Many encourage the woman to hold her baby and to use the "feel" of it to develop an instinct for its needs. Other midwives will advise the mother to keep the baby in bed with her for the first few days after birth; they feel that both the mother and the baby will be more content and better able to rest. Id. at 183-84.

73 A similar "crisis" occurred in the mid-seventies. Many doctors found themselves without insurance altogether, and many went on strike to protest the situation. See Defensive Medicine Hearing, supra note 7, at 29-30 (statement of Arnold J. Rosoff, J.D., Associate Professor, Wharton School of Business, University of Pennsylvania); Montgomery, Doctors Planning Treatment Curbs in Insurance Fight, N.Y. Times, Apr. 28, 1975, at A1, col. 4.

74 Insurance problems have affected the entire medical profession, see supra note 7 , as well as other industries and professions. See, e.g., Fish, N.J. Fisherman Consider Forming an Insurance Co-op, Philadelphia Inquirer, Dec. 7, 1985, at 11-D, col. 1 (commercial fishermen); Fish, On Thin Ice Without Insurance, Philadelphia Inquirer, Nov. 3, 1985, at $\mathrm{H} 1$, col. 1 (ice skating rinks); Sugaward, "Hysteria" in Day-Care Crisis Cited, Washington Post, July 31, 1985, at B2, col. 1 (day-care centers); Broder, Insurance Liability is at a Premium, L.A. Times, July 14, 1985, $\S \mathrm{V}$, at 1, col. 6 (liability insurance for corporate officers and directors).

The entire property and casualty insurance industry has suffered considerable losses as a result of this problem. See Keppel, Liability Insurers are Fleeing Field in Wake of Big Damage Awards, L.A. Times, June 17, 1985, § IV, at 1, col. 5; 1984 Seen as Worst Year Ever: Losses Outpaced Investment Income, Nat'l Underwriter, Jan. 11, 1985, at 1, col. 2.

${ }_{75}$ See Kolbert, supra note 2. Despite these statistics, insurers justify the increased rates by reference to the increase in the number of malpractice suits and high jury 
There are several factors that may account for this difference. The relationship between a midwife and her client is normally very close. The woman and her midwife work together to bring about a successful birth and thereby develop a relationship that is different from the average doctor-patient relationship. Thus, the breakdown of the doctor-patient relationship that many commentators cite as contributing to the rise in malpractice suits ${ }^{76}$ is not a factor in the midwife context.

That midwives work only with low-risk women ${ }^{77}$ also contributes to the low percentage of suits brought against them. It is highly probable that a woman attended by a midwife will have an uneventful pregnancy and birth and, therefore, will have no reason to sue. Moreover, the cautious attitude of midwives toward the potential overuse of medical technology and drugs ${ }^{78}$ lessens the likelihood of suit against them.

Regardless of the reasons why midwives should not be affected by the crisis, the fact is that the present insurance crisis is a particular hardship for them. Today's problem is one of affordability rather than availability. Because doctor-owned insurance companies and joint underwriting associations were formed in response to a 1970's insurance crisis, ${ }^{79}$ most doctors can now obtain malpractice insurance, albeit at an extremely high cost. ${ }^{80}$ For midwives, however, the crisis of affordability means that insurance is simply not available. Midwives do not earn the large salaries of doctors, and it is more difficult for them to pass the increased cost of insurance on to their clients. ${ }^{31}$ Therefore, merely making insurance available will not ease the crisis facing midwives.

Efforts to insure midwives through joint underwriting associations

awards. They also question the concept of a low-risk birth. One insurer asked, "How do you know it's a low-risk birth until after it's over?" Id. (quoting Philip Bies, President, Medical Malpractice Insurance Association).

76 See supra note 52.

77 See supra note 39 and accompanying text.

78 See supra notes $49-50,67$ and accompanying text.

79 More than 20 states authorized the creation of joint underwriting associations in 1975. See A Legislator's Guide to the Medical Malpractice Issue 4-5 (D. Warren \& R. Merrit eds. 1976) [hereinafter cited as A Legislator's GuIDE]. The concept behind these associations was to force insurers to provide malpractice coverage by allowing them to share any resulting losses. A limited number of companies continued to provide malpractice coverage, but all companies had to share in any losses. In return, the insurers retained the right to carry other, more lucrative types of liability insurance. See id.

80 See Defensive Medicine Hearing, supra note 7, at 105-07 (statement of John E. Rolig, Underwriting Officer, Medical Services Division, St. Paul Fire and Marine Insurance $\mathrm{Co}$.).

81 See supra note 62 and accompanying text. Part of the attractiveness of the midwife option is the affordability of midwives' services, particularly for low-income families. See supra note 11 and accompanying text. Forcing a midwife's clients to absorb the cost of a high insurance premium would eliminate this advantage. 
have been unsuccessful because they have offered either excessive premiums or an insufficient amount of coverage. ${ }^{82}$ To date, only one state, New Jersey, has offered midwives insurance from a private carrier. ${ }^{83}$ Thus, the current state of the malpractice insurance market makes it impossible for midwives to practice their profession.

Midwives face a special problem, and actions taken that may lessen the crisis for doctors will not necessarily do the same for midwives. The malpractice problem, moreover, is a particularly intractable one, and a long-range solution does not appear imminent. Although a detailed analysis of all of the causes, effects, and potential solutions is beyond the scope of this Comment, ${ }^{84}$ it is necessary to set out a brief history of the problem in order to demonstrate that a long-range solution is likely to be many years away.

\section{B. Why So Many Malpractice Suits?}

The malpractice crisis is characterized by an increase in the number of suits and the amount of awards. These increases have made insurers reluctant to underwrite malpractice insurance and have caused those that do to charge increasingly higher premiums.

There is much disagreement as to the causes of the current problem. Doctors blame lawyers and the legal system; ${ }^{85}$ in turn, lawyers

82 See K. McHugh, supra note 3, at 8. Efforts are currently underway in Pennsylvania to insure midwives through that state's joint underwriting association, and it is not yet known whether these efforts will be as unsuccessful as similar efforts in other states have been. See Quarembo, supra note 2. For a brief discussion of joint underwriting associations, see supra note 79.

${ }^{83}$ See K. McHugh, supra note 3, at 8. The annual premium for this policy is $\$ 1,709$. See Kolbert, supra note 2, at A56, col. 1. In comparison, many obstetricians pay more than $\$ 80,000$ a year for insurance. See id.

84 Much has been written on the subject of medical malpractice and the myriad problems associated with it. See, e.g., S. LAw \& S. Polian, PaIn and Profit: The Politics of Malpractice (1978) (presenting a comprehensive treatment of the malpractice problems from the perspectives of the medical, legal, and insurance systems, addressing such issues as the contingency fee and no-fault alternatives); T. LOMBARDI, Medical Malpractice Insurance: A LegislatoR's View (1978) (presenting an overview of the malpractice problem and New York State's response to it); Learner, Restrictive Medical Malpractice Compensation Schemes: A Constitutional "Quid Pro Quo" Analysis to Safeguard Individual Liberties, 18 HARv. J. ON LEGIS. 141 (1981) (examining legislative responses to malpractice litigation, such as dollar recovery limitation and arbitration procedures); Note, Comparative Approaches to Liability for Medical Maloccurrences, 84 YALE L.J. 1141 (1975) (advocating ways to achieve economic efficiency and cost-cutting in health care and malpractice litigation).

${ }_{83}$ See Defensive Medicine Hearing, supra note 7, at 165-66 (statement of Elvoy Raines, Associate Director, Dep't of Professional Liability, American College of Obstetricians and Gynecologists) (criticizing large jury awards and their impact on physicians); T. LOMBARDI, supra note 84, at 23-24 (noting, in part, that doctors believe lawyers are building a malpractice practice to compensate for the reduction of suits due 
blame doctors and the insurance industry. ${ }^{86}$ Despite these conflicting accusations, commentators suggest a number of possible causes of the dramatic increase in malpractice suits. First, increasing specialization and subspecialization in medicine have changed the basic doctor-patient relationship. ${ }^{87}$ Doctors are no longer familiar friends, but strangers. Second, as medical technology becomes more complicated, chance of human error increases. ${ }^{88}$ Further, even slight errors in judgment can have major consequences for the patient in terms of pain and disability. Finally, consumerism and somewhat unrealistic expectations about the capacities of modern medicine have combined to make patients less trusting and more willing to blame the doctor for an adverse outcome. ${ }^{89}$

The legislative response to the problem has generally been to pass hastily drafted legislation aimed at alleviating the "crisis" with little intensive study of its root causes. ${ }^{90}$ The existence of the present "crisis"

to no-fault insurance in other areas); Pabst, A Medical Opinion Survey of Physicians' Attitudes on Medical Malpractice, in HEW REPORT, supra note 7, at 83, 84 (stating that $30 \%$ of the doctors who were sued claimed that aggressive lawyers are "the single most common cause of malpractice suits today"); Malcolm, Doctors Prepare Attack on Suits for Malpractice, N.Y. Times, Feb. 15, 1985, at A1, col. 2.

${ }_{86}$ See Gesler, Aiken, Gleisner, Domnitz \& Antoine, Medical Malpractice: Eliminating the Myths, 68 MARQ. L. REv. 259, 263 (1985) (The cause of the "crisis" is "the failure of the Medical Society and the insurance industry to identify, discipline, and remove from the profession those health care providers who through their negligence cause untold suffering and injury to an unsuspecting public.") (footnote omitted); Keene, California's Medical Malpractice Crisis, in A Legislator's Guide, supra note 79, at 27, 28 ("[T] he legal societies in California . . . have been very adamant in their position that the cause of the current crisis has been the unrestricted investment policies of insurance companies accompanied by rampant medical malpractice by physicians."); Londrigan, The Medical Malpractice "Crisis," TRIAL, May 1985, at 22, 24 (arguing that the insurance industry's exemption from the antitrust laws and the industry's freedom from effective rate regulation caused the dramatic rise in medical malpractice rates).

Insurers have not been above defending themselves and casting a few accusations of their own. See Brostoff, Blasts Lawyer Charge That Industry Is Creating A Malpractice Crisis, Nat'l Underwriter, Apr. 19, 1985, at 1. col. 2 (noting that 'less than three percent of all companies are offering [malpractice insurance]" and that "trial lawyers [are] using 'smoke and mirrors' to advance their own narrow self-interest").

${ }^{87}$ Doctors are now perceived to be impersonal and inconsiderate, unlike the traditional small-town physician with his little black bag. See Mechanic, Some Social Aspects of the Medical Malpractice Dilemma, 1975 Duke L.J. 1179, 1184; see also supra note 52 and accompanying text.

8s See Mechanic, supra note 87 , at 1181-82.

B9 See New York RePort, supra note 52, at 9-10; see also Defensive Medicine Hearing, supra note 7, at 174 (statement of John R. Ball, Associate Executive Vice President for Health and Public Policy, American College of Physicians) ("Patients have come to expect that complex machinery, sophisticated hospitals, and super-specialized personnel should produce improved health outcomes. When they do not, and especially when they produce an adverse result, the patient is apt to feel aggrieved.").

${ }_{90}$ See S. Law \& S. Polan, supra note 84, at 207. Law and Polan suggest that legislators were greatly influenced by physicians' threats and that they based their actions on "woefully inadequate data and misconceptions of legal doctrines . . . ." Id. at 
is proof that the rash of legislation passed in response to the last crisis has not been successful.

\section{G. Possible Solutions}

\section{Tort Reforms and Forum Shifting}

State reforms previously attempted fall into two major categories: tort reform and shifting the forum in which malpractice suits are brought from the traditional courtroom setting to a less adversarial arbitration proceeding or screening panel. Both of these efforts have run into problems in the courts, and neither has had the desired effect of reducing the number of suits or the size of awards.

Tort reforms aimed at the medical malpractice problem include limiting contingent fees, ${ }^{91}$ shortening statutes of limitation, ${ }^{92}$ eliminating the ad damnum pleading, ${ }^{98}$ and placing ceilings on recovery. ${ }^{94}$ The fairness of some of these measures has been questioned, ${ }^{95}$ and some

206.

21 See, e.g., CaL. Bus. \& Prof. Code § 6146 (West Supp. 1986) (adopting a sliding scale in which the percentage of recovery allocated to the fee declines as the amount recovered increases); Iowa Code ANN. § 147.138 (West Supp. 1985) (requiring the trial court to determine the reasonableness of contingent fee arrangements).

${ }_{22}$ See, e.g., Mass. ANN. Laws ch. 260, \& 4 (Michie/Law. Co-op. Supp. 1985) (providing for a limitation of three years from the date on which the cause of action accrues in the case of a minor, rather than the 20-year limitation on most causes of action); Mich. CoMP. LAws ANN. §§ 600.5805(4), 600.5838(2) (West Supp. 1985) (providing for a two-year statute of limitations with a six-month extension from the time of discovery if the plaintiff can prove that she should not have discovered the injury earlier); N.Y. Crv. Prac. LAw \& 214-a (McKinney Supp. 1985) (providing that a medical malpractice cause of action accrues in two years and six months from the date of discovery, rather than in three years, the period applicable to other malpractice actions).

93 The ad damnum pleading permitted or required the plaintiff to set forth in her complaint the amount of money she was seeking. For statutes abolishing this requirement, see, for example, FrA. STat. ANN. § 768.042(1) (West Supp. 1985) (abolishing pleading of the amount of general damages but permitting pleading of the amount of special damages); IND. CODE ANN. § 16-9.5-1-6 (West Supp. 1985) (stating that "no dollar amount or figure shall be included in the demand in any malpractice complaint, but the prayer shall be for such damages as are reasonable in the premises").

o4 See, e.g., LA. Rev. Stat. ANN. § 40:1299.42(B)(2) (West Supp. 1986) (A qualified health care provider is not liable for more than $\$ 100,000$ per patient.); WIS. STAT. ANN. § 655.23(5) (West 1980) (A qualified health care provider is liable for "no more than $\$ 200,000$ per claim and $\$ 600,000$ per year or the maximum liability limit for which the provider is insured, whichever is higher."); see also Comment, Medical Malpractice: A Sojourn Through the Jurisprudence Addressing Limitation of Liability, 30 Lox. L. REv. 119 (1984) (analyzing the constitutionality of Louisiana's limitation-on-liability provision). For a survey of state reforms in general, see Comment, An Analysis of State Legislative Responses to the Medical Malpractice Crisis, 1975 Duke L.J. 1417.

os See Defensive Medicine Hearing, supra note 7, at 31-32 (statement of Arnold J. Rosoff, J.D., Associate Professor, Wharton School of Business, University of Penn- 
state courts have found them unconstitutional..$^{96}$ Furthermore, in practice they have had little effect on the problem. ${ }^{97}$

A number of states have tried changing the forum in which malpractice suits are brought in an attempt to reduce both the administrative costs associated with bringing a malpractice suit and the amount of awards..$^{88}$ Many states have instituted various forms of arbitration proceedings or screening panels. ${ }^{99}$ For the most part, however, these reforms have not been effective. ${ }^{100}$ In fact, the delays associated with the arbitration and panel systems have led some state courts to find them

sylvania) ("[T]he solution to increased malpractice litigation is not simply to make it harder for aggrieved patients to sue . . .."); id. at 204-06 (statement of Thomas Dendorf, Executive Director, Association of Trial Lawyers of America) (criticizing laws that respond to the medical malpractice crisis by making it more difficult for people to sue "when wronged"); Learner, supra note 84, at 147, 187-89 ("[Legislative] efforts to alleviate the medical malpractice insurance crisis . . . have placed the brunt of such reform on those least able to bear its burdens-future medical malpractice victims.").

${ }^{*}$ Courts in Illinois, New Hampshire, North Dakota, and Ohio have held unconstitutional the imposition of monetary limitations on recoveries in medical malpractice cases. See Wright v. Central Du Page Hosp. Ass'n, 63 Ill. 2d 313, 347 N.E.2d 736 (1976); Garson v. Maurer, 120 N.H. 925, 424 A.2d 825 (1980); Arneson v. Olson, 270 N.W.2d 125 (N.D. 1978); Simon v. St. Elizabeth Medical Center, 3 Ohio Op. 3d 164, 355 N.E.2d 903 (Ct. C.P. Montgomery County 1976). But see Fein v. Permanente Medical Group, 695 P.2d 665, 679-84, 211 Cal. Rptr. 368, 382-87 (1985) (en banc) (upholding CaL. Crv. CoDE § 3333.2(b) (West Supp. 1986), which limits noneconomic damages in medical malpractice suits to $\$ 250,000$ ).

97 See Defensive Medicine Hearing, supra note 7, at 28 (statement of Arnold J. Rosoff, J.D., Associate Professor, Wharton School of Business, University of Pennsylvania) ("Sadly, it is clear now, almost a decade later, that these various legislative fixes have not been wholly effective."); S. LAw \& S. Polan, supra note 84, at 206 ("These changes have little impact on the costs of malpractice insurance.").

${ }_{88}$ See Defensive Medicine Hearing, supra note 7, at 32 (statement of Arnold J. Rosoff, J.D., Associate Professor, Wharton School of Business, University of Pennsylvania) (stating that $86 \%$ of premiums paid for malpractice liability insurance go to operate the claims resolution system rather than to pay compensation to injured patients); Comment, supra note 94, at 1463 (The advantages of alternative forums over the jury trial are "speed, informality, and the use of a sophisticated decision-maker in a matter of technical complexity.") (footnote omitted). It is argued that experts, understanding medical jargon and procedures, will be better able to evaluate a case on its merits and will likely give lower awards than juries who may be deciding cases based on sympathy rather than a clear understanding of the facts.

sə See, e.g., ARk. STAt. ANN. \$\$ 34-2602 to -2605 (Supp. 1983) (screening panel); Cal. Giv. Proc. Code \& 1295(a)-(b) (West 1982) (allowing medical contracts that include arbitration clauses); IND. CODE ANN. § 16-9.5-9-1 (West 1984) (screening panel); OHio Rev. Cone AnN. § 2711.21 (Page 1981) (arbitration panel); WIS. STat. ANN. § 655.02 (West 1980) (arbitration panel).

${ }_{100}$ See, e.g., MacAlister \& Scanlan, Health Claims Arbitration in Maryland: The Experiment Has Failed, 14 U. BALT. L. REv. 481 (1985) (stating that in Maryland the use of arbitration to resolve health claims has failed to reduce the number of suits, size of awards, or delay in resolving claims). But see Daughtrey \& Smith, Medical Malpractice Review Panels in Operation in Virginia, 19 U. RicH. L. REv. 273, 298 (1985) (stating that the panels seem to be working but that it may be too soon to determine their constitutionality). 
unconstitutional. ${ }^{101}$ Since forum shifting has not had the intended effect of speeding up the process and reducing administrative costs, ${ }^{102}$ such reforms are not likely to reduce the cost of malpractice insurance.

\section{No-Fault Proposals}

Recognizing that tort reform and forum shifting are ineffective, some commentators have advocated abandoning the present fault-based tort system altogether and instituting a no-fault system modeled on automobile no-fault insurance. ${ }^{103}$

The central concept of the various no-fault proposals is that of "iatrogenic injury": the patient is compensated for any injury caused by medical treatment, whether or not negligence was involved. ${ }^{104}$ Several

101 See, e.g., Aldana v. Holub, 381 So. 2d 231, 236-27 (Fla. 1980) (holding that arbitration procedures so extended the process of suing for malpractice that they effectively denied access to the courts); Mattos v. Thompson, $491 \mathrm{~Pa} .385,396,421$ A.2d 190,196 (1980) (striking down a provision of Pennsylvania law that gave original, exclusive jurisdiction over medical malpractice claims to arbitration panels, because delays in processing claims under the arbitration system resulted in an impermissible infringement on the right to a jury trial).

${ }^{102}$ There is a compelling reason why the difficulty of arbitration-induced delay exists: the constitutions of 48 states guarantee the right to jury trial. See Comment, supra note 94 , at 1466 . These constitutional provisions make it difficult to require that mandatory arbitration be the final, binding resolution of a malpractice conflict. As a result, the arbitration procedure, rather than promoting efficiency and savings, has become an added step in an already long and protracted type of litigation.

103 See, e.g., NEw York REPORT, supra note 52, at 57-63, 129-37; Havighurst, "Medical Adversity Insurance"-Has Its Time Come?, 1975 Duke L.J. 1233; Havighurst \& Tancredi, "Medical Adversity Insurance"-A No-Fault Approach to Medical Malpractice and Quality Assurance, 1974 INs. L.J. 69; O'Connell, Expanding NoFault Beyond Auto Insurance: Some Proposals, 59 VA. L. Rev. 749 (1973).

${ }_{104}$ More than one model of a no-fault system has been suggested. See, e.g., Havighurst, supra note 103, at 1254-63; Havighurst \& Tancredi, supra note 103, at 71 (contemplating a system using detailed lists of the adverse consequences of certain medical procedures for which the patient would be compensated regardless of fault); O'Connell, Elective No-Fault Liability by Contract-With or Without an Enabling Statute, 1975 U. ILL. L.F. 59, 62 (suggesting a system in which physicians elect to pay on a no-fault basis for injuries they cause and in which coverage is limited to any class of risks the doctors choose, while other injuries would remain subject to the traditional tort system); see also O'Connell, Offers That Can't Be Refused: Foreclosure of Personal Injury Claims by Defendants' Prompt Tender of Claimants' Net Economic Losses, 77 Nw. U.L. REv. 589, 601 (1982) (proposing a statute that would give a defendant "against any claim for personal injury the option of foreclosing such claim by offering, within sixty days of the claim, to pay the claimant's net economic losses" not covered by the claimants' collateral sources) (footnote omitted).

Richard Epstein, who does not subscribe to the no-fault approach, see Epstein, Medical Malpractice: Its Cause and Cure, in THE Economics of Medical MaLPRACTICE 245, 257-67 (S. Rottenberg ed. 1978) [hereinafter cited as Epstein, Cause and Cure], suggests yet another approach to the problem. He proposes that the problem of personal injury in malpractice cases is one not for tort law, but for private agreements between physicians, hospitals, and patients setting the terms on which medical services are rendered. See Epstein, Medical Malpractice: The Case For Contract, 
failings of the tort system have prompted these proposals. The current tort system is criticized for the high administrative costs and delay involved in claims processing and fault finding, ${ }^{105}$ for the growth of defensive medicine, ${ }^{106}$ and for the fact that many patients who suffer injuries due to medical treatment are not compensated under the present system because the amount of damage they suffer does not make a suit economically feasible. ${ }^{107}$ Many commentators, however, continue to stress the deterrent effects of the current system and insist that a nofault system is too problematic and uncertain to succeed. ${ }^{108}$ Moreover, several problems in applying a no-fault system to the field of medicine make the ultimate success of such a system in stemming the high cost of malpractice insurance highly unlikely.

The most difficult aspect of a no-fault system is defining a "compensable" event. Although proponents claim that it is feasible to develop lists of compensable events, ${ }^{109}$ the inherent characteristics of medical injury make it extremely difficult to do so. ${ }^{110}$ In the automobile

1976 Am. Bar Found. Research J. 87. There are numerous problems with such a proposal, the most pressing of which is the unequal bargaining power of a patient who is in need of medical services.

${ }^{108}$ In 1975 in New York, 250 million dollars in premiums were collected, and only 25 to $40 \%$ of the premiums were eventually paid out to injured patients. See NEw YORK REPORT, supra note 52, at 156. A study done in California in 1975 reported that in premium years 1962 to $1972,46 \%$ of fees were consumed by litigation, $20 \%$ were spent on administrative costs, and, at most, $34 \%$ were received by plaintiffs as direct compensation for injuries suffered. See Keene, supra note 86, at 29.

${ }^{108}$ Defensive medicine is generally defined as the use of medical resources primarily for the purpose of protecting the physician against a claim rather than for the patient's well-being. The AMA Committee on Professional Liability estimated that the total cost of defensive medicine in 1983 was $\$ 15.1$ billion. See Defensive Medicine Hearing, supra note 7, at 5 (statement of Sen. Orrin G. Hatch).

${ }_{107}$ Although many lawyers argue that the contingent fee system is invaluable because it allows those who would not otherwise be able to afford suits to bring them, it also has the opposite effect: it discourages lawyers from taking cases in which the prospects of success may be very good but the economic damage to the patient is small. See S. LAw \& S. Polan, supra note 84, at 84-85.

${ }^{108}$ See Defensive Medicine Hearing, supra note 7, at 6-7 (statement of Patricia M. Danzon, Ph.D., Associate Professor of Economics, Duke University) (arguing that the powerful deterrent effects of the current malpractice structure would be lost under a no-fault system); id. at 42 (statement of Barry F. Furrow, Associate Professor of Law, University of Detroit) ("[A]s a quality control device, [the tort system] has a great deal of value."); S. LAW \& S. PolaN, supra note 84, at 155-56 (arguing that it would be dangerous to abandon the current system in favor of a no-fault system because we would lose the deterrent effect of existing tort law).

109 See ABA Comm'n on Medical Professional Liability, Designated Compensable Event System: A Feasibility Study 5 (1979); Havighurst, supra note 103, at 1256-59; Havighurst \& Tancredi, supra note 103, at 75-76.

${ }_{110}$ Several commentators suggest that the problem of defining a compensable event in the medical context is nearly insurmountable. See, e.g., S. LAw \& S. PolaN, supra note 84, at 150 ("Defining what constitutes a compensable event is enormously difficult."); Epstein, Cause and Cure, supra note 104, at 260-64. 
context, it is fairly easy to determine whether an injury results from use of an automobile. In the medical context, where the patient often is ill from the start, however, it is difficult to determine whether a particular injury results from treatment or from the condition that brought the patient to the physician in the first place. Because of this difficulty, little savings in time or administrative costs would be realized under a medical no-fault system. ${ }^{111}$ The need for litigation would not be eliminated; rather, the focus of litigation would merely shift from whether the physician has been negligent to whether the injury was related to treatment. ${ }^{112}$

Even if an acceptable solution to the problem of defining a compensable event were found, a no-fault system would likely be considerably more expensive than the present system of malpractice liability insurance. ${ }^{113}$ A no-fault system compensates injured persons whom the present system excludes. Although proponents of no-fault insurance claim that savings in administrative costs, elimination of duplicate payments for injuries, and elimination of damages for non-economic injuries ${ }^{114}$ would offset the increase in the number of claims paid, there is considerable evidence to the contrary. ${ }^{115}$ Experience with automobile no-fault does not support the belief that the adoption of a no-fault system would lead to a decrease in costs; ${ }^{116}$ the difficulties in defining

111 See Note, supra note 84, at 1163 (concluding that "[a] dramatic savings in administrative costs is less likely to materialize with medical care strict liability than with strict liability in other tort areas, because of the difficulties in determining iatrogenicity [treatment-induced injuries]").

${ }_{112}$ An analogous problem arises in the area of workers' compensation, for which a whole body of case law has developed concerning whether a particular injury occurred within the scope of employment. See, e.g., Morgan v. Industrial Comm'n, 89 Ill. 2d 502, 506, 433 N.E.2d 1305, 1306 (1982) (upholding a finding of the industrial commission that the claimant failed to prove that his accident arose out of and in the course of his employment); Oakes v. Workmen's Compensation Appeal Bd., $79 \mathrm{~Pa}$. Commw. 454, 460, 469 A.2d 723, 726 (1984) (holding that an electric company foreman who was returning from work at the site of a power outage was acting "in the course of his employment" at the time of his fatal accident).

113 See S. LAw \& S. Polan, supra note 84, at 152-54; see also T. Lombard, supra note 84 , at 136 (predicting that the adoption of a no-fault system "could be catastrophic in terms of health care costs").

114 See Havighurst, supra note 103, at 1270-72.

11 See supra notes 109-12 and accompanying text; see also Keeton, Compensation for Medical Accidents, 121 U. PA. L. Rev. 590, 616 (1973) (concluding that "a shift from fault to nonfault . . . in the medical accident field, rather than leading to improved efficiency and lower overall costs, would lead to only slight improvement in efficiency and to substantially higher overall costs").

${ }^{116}$ See T. Lombardi, supra note 84, at 136; S. LAw \& S. Polan, supra note 84, at 152; see also Maroney, No-Fault Automobile Insurance: $A$ Success or Failure After Eleven Years?, 51 INS. CounSEL J. 75, 75-76 (1984) (arguing that the no-fault concept remains valid but that there are deficiencies in the current law that undermine its operation); Comment, Michigan No-Fault: The Rise and Fall of Socialized Negligence, 56 
compensable events make administrative savings even less likely in the medical context.

In addition, any deterrent effect of the present system ${ }^{117}$ would be lost under a no-fault plan. The history of the medical profession in policing itself suggests that peer review would not be a satisfactory alternative. ${ }^{118}$ In sum, a no-fault solution, if possible at all, is many years from fruition and is not likely to help midwives stave off the present crisis.

\section{The Insurance Industry}

Although commentators differ as to the insurance industry's role in the present malpractice crisis, ${ }^{119}$ it is obviously one of the key actors and a possible target of reform. There are, however, several aspects of the industry that make reform difficult.

Insurers earn profits in two ways: from underwriting operations in which the losses and expenses are less than the amount of premiums received and from investments of premium fees. ${ }^{120}$ Often, profits made on the investment side offset any underwriting losses; in such cases, premiums need not increase. ${ }^{121}$ This was particularly true in the malpractice area, which many insurers perceived to be profitable only because of investment opportunity, and not because of possible underwriting profits. ${ }^{122}$ This strategy operated effectively as long as the insurance companies did not sustain losses on their investments. When losses oc-

U. DET. J. URB. L. 99, 109-20 (1978) (arguing that the no-fault system in Michigan failed because there was no reduction in insurance rates and no reduction in the caseload of the courts).

117 See supra note 108 and accompanying text.

${ }^{128}$ See Kendall, Expectations, Imperfect Markets, and Medical Malpractice Insurance, in The Economics of MEDICAL MAlPRACTICE, supra note 104, at 167, 190 (arguing that the record of physicians in policing themselves "is indefensible. . . . [S]tates should not abdicate their responsibility [for regulation] to physician groups.").

119 Some commentators argue that the insurance industry at least took advantage of the malpractice insurance crisis and in fact may have invented it. See S. LAw \& S. POLAN, supra note 84, at 161-70. Others contend that the insurance industry was just another victim. See, e.g., T. LoMBARDr, supra note 84, at 1-19.

120 Investment income is an important part of the economics of the insurance industry. See Kimball \& Denenberg, The Regulation of Investments: A Wisconsin Viewpoint, in Insurance, Government, and Social Policy: Studies In Insurance Regulation 126, 127 (S. Kimball \& H. Denenberg eds. 1969).

121 "On the property-liability side of the business, investment income has kept many an insurer safely afloat ...."Id. at 127.

${ }^{122}$ The extended length of time between premium collections and claim disbursements encouraged insurers to write malpractice insurance, knowing that they could hold and invest premium income to offset underwriting deficits. See S. LAw \& S. PoLAN, supra note 84, at 169. 
curred in the mid-seventies and again recently, ${ }^{123}$ insurers were forced to satisfy claims out of "surplus" - the amount by which an insurer's assets exceed its liabilities-which in turn reduced the surplus and made it difficult to write additional policies. ${ }^{124}$ Insurers, perceiving a danger in relying solely on investment income both to absorb the costs of claims and to provide a profit, ${ }^{125}$ sought to raise premiums in order to decrease their underwriting losses. In part due to unrealistic assessments of premiums prior to this time, ${ }^{128}$ the requested increases were large, and doctors and hospitals rebelled against them. ${ }^{127}$

Certain characteristics of malpractice claims make predicting proper premium rates difficult. First, the statistical base from which actuaries attempt to predict cost is minuscule in comparison with other liability lines, ${ }^{128}$ reducing the credibility of past data for predicting future losses. Second, it cannot be assumed that the conditions existing during any given base period will remain the same during the next policy period. Several factors combine to create this difficulty. Of particular significance is the "long tail" nature of malpractice claims, under which a large number of the claims on a given policy will not be made until many years after the policy is written. ${ }^{129}$ Compounding this

.228 Until now, the years 1974 and 1975 were the worst years since the 1930's for both underwriting and investment losses in the industry. See Roddis \& Stewart, The Insurance of Medical Losses, 1975 DukE L.J. 1281, 1288. Insurers recently sustained similarly disastrous losses. See supra note 74 and accompanying text.

${ }^{124}$ Insurers are required by statute to make a minimum commitment of capital. See E. Patterson, Essentials of Insurance Law 25-26 (1957). In addition, they must maintain a reasonably constant proportion of premium volume to surplus. See id. Erosion of surplus resulting from underwriting and investment losses thus reduces the volume of insurance that an insurer can write. See Roddis \& Stewart, supra note 123, at $1285-87$.

${ }^{125}$ Some commentators cite the "psychological" effect of the increase in losses on insurance companies as a factor in the ensuing crisis. See Roddis \& Stewart, supra note 123, at 1288; S. LAW \& S. Polan, supra note 84, at 168-69.

128 Inadequate premiums were blamed for part of the problem in the 1970's. One study concluded that the insurance industry contributed to the crisis through poor pricing and that physicians in California had been paying inadequate premiums for 15 years. See NEW YORK REPORT, supra note 52, at 222. A recent example of the same phenomenon is the rates that nurse-midwives paid prior to the present crisis: $\$ 38$ per year for the last 12 years. Telephone interview with Karen Ehrnman, Government Relations Coordinator, ACNM (Oct. 18, 1985).

127 In the 1970's many state insurance regulators refused to grant insurance companies the large rate increases they sought. This prompted some companies to threaten to pull out of the business. See T. LoMBaRdi, supra note 84 , at 5 . Where the increases were granted, doctors protested, and some refused to provide medical services. See Montgomery, supra note 73, at A1, col. 4.

${ }_{128}$ See Roddis \& Stewart, supra note 123, at 1294; S. LAw \& S. Polan, supra note 84 , at $178-79$.

120 The "tail" of malpractice coverage is the time lag "between the date of the act or omission for which the claim is made and the date of the final disposition." $T$. LOMBARDI, supra note 84, at 6 (citation omitted). Discovery rules are primarily re- 
problem is the fact that most medical malpractice insurance is written on an occurrence basis rather than a claims-made basis. ${ }^{130}$

Changing social conditions and the legal climate also contribute to the problem. With tort doctrines in a constant state of flux, and with an increase in both the willingness to sue and the success rate of lawsuits, ${ }^{131}$ it is difficult to predict the amount that will have to be paid on a claim that will not be made for a number of years. These factors have combined to make the actuary's job-predicting future liabilities on the basis of past experience and setting premium rates accordingly-extremely difficult. In addition, the insurance carriers' practice of not settling claims without the physiçian's approval, ${ }^{\mathbf{1 3 2}}$ doctors' difficulty in obtaining reinsurance, ${ }^{\mathbf{1 3 3}}$ and the ineffectiveness of state regulation $^{134}$ have further exacerbated the problem. Thus, although reform of

sponsible for the long tail of malpractice claims. Under these rules the statute of limitations does not begin to toll until the injury is discovered or should have been discovered. See HEW REPORT, supra note 7, at 126-27. Due to the long tail, insurers are often forced to keep accounts open for at least 10 years, and over $10 \%$ of the actual payments may be made later than that. See New YoRk REPORT, supra note 52, at 220.

130 Under an occurrence policy, an insurer is liable for any claims that occur in the policy year, regardless of when they are filed. Under a claims-made policy, insurers are liable only for claims brought within the policy year. The advantage of the latter approach for insurers is that it eliminates claims incurred but not reported during the policy year and, hence, shortens the time between prediction and payment. See Roddis \& Stewart, supra note 123, at 1297; see also NEw YORK REPORT, supra note 52, at 229 (stating that the claims-made approach may "offer some potential benefits to both the insurer - by rationalizing his price-and the practitioner-by enabling a more realistic decision to be made concerning policy limits"); Comment, The "Claims-Made" Dilemma in Professional Liability Insurance, 22 UCLA L. Rev. 925, 927 (1975) (concluding that claims-made policies contain a valid limitation on coverage and can be advantageous to both insureds and insurers).

Medical care providers are often wary of claims-made policies because they fear having no coverage upon death or retirement. In response to this concern, some insurers have made a contractual commitment to provide this coverage. See S. LAw \& S. PoLAN, supra note 84, at 187.

131 See NEW YoRK REPORT, supra note 52, at 220-21 (discussing the rise in the number of personal injury and medicial malpractice cases since World War II); Epstein, Cause and Cure, supra note 104, at 245-54 (discussing the expansion of negligence theory); Roddis \& Stewart, supra note 123, at 1299-300 (stating that there has been an increasing trend over the past 25 years to translate medical injuries into legal liability claims).

132 See T. Lombardi, supra note 84, at 6-7. Removal of the consent clause from medical malpractice policies might make claims handling more efficient. See id.

133 The difficulty of obtaining reinsurance has had some effect on the availability of primary insurance, although how much is not known. See id. at 14. Some states sought to alleviate the insurance crisis of the mid-seventies by guaranteeing reinsurance on policies that insurers determined to be bad risks. See S. Law \& S. Polan, supra note 84 , at 197-98.

194 Under the McCarran-Ferguson Act of 1945, Pub. L. No. 79-15, 59 Stat. 33 (codified as amended at 15 U.S.C. \$§ 1011-1015 (1982)), insurance companies are exempt from prosecution for most federal antitrust violations to the extent that they are regulated by state law. See 15 U.S.C. § 1012 (1982). Although any acts or agreements 
the insurance industry may partially relieve the malpractice crisis, this method of reform is illusive and unlikely to provide a full answer to the current problem.

\section{Solutions: The Possibility of Self-Insurance}

There are no easy answers to the medical malpractice problem, either in general or as it affects midwives. Midwives are the victims of a set of circumstances that are beyond their control. They are unable to obtain affordable malpractice insurance, not because of a high degree of negligent behavior in the midwifery profession itself, ${ }^{135}$ but because of increases in the number of suits and size of awards brought against the medical profession in general, ${ }^{136}$ and the insurance industry's perception that malpractice insurance has ceased to be a profitable enterprise. ${ }^{137}$

Although a solution to the larger medical malpractice problem is necessary if Americans are to continue to enjoy high-quality medical care, ${ }^{188}$ the complex nature of the problem makes satisfactory solutions

to "boycott, coerce, or intimidate" are still proscribed by federal law, see id. $\S 1013$ (b), this exemption has meant that the primary regulation of the industry occurs at the state level.

Several commentators have questioned the ability of the states to regulate an industry that has become national in scope. See, e.g., CoMptroller General OF THE

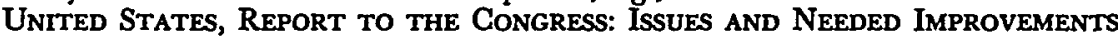
IN State Regulation of THE InSURANCE Business 182-83 (1979) (concluding that many problems in the industry are not merely local and that many state regulators lack the necessary data to address even local problems adequately); S. LAw \& S. Polan, supra note 84, at 188-92; T. LOMBARDI, supra note 84, at 17; E. PATTERSON, supra note 124, at 6 (noting that the low standards and inefficient methods of supervision by some states threaten the continuance of state regulation); Kimball \& Denenberg, supra note 120 , at $11-13$ (noting that the limited capacity and resources of Wisconsin's insurance department limit its ability to regulate).

${ }^{135}$ Only six percent of the country's midwives have been named in malpractice suits, as compared with $60 \%$ of obstetricians. See supra note 75 and accompanying text.

138 The ACNM has launched a campaign to convince insurers that midwives are a safer risk than obstetricians. To date these efforts have been unsuccessful. See K. McHugh, supra note 3, at 7. Insurers do not accept the concept of a low-risk birth, see supra note 75, and insist on including midwives in the same high-risk category as obstetricians.

${ }^{137}$ See supra notes $122-26$ and accompanying text.

188 Some commentators contend that the threat of malpractice suits has already lowered the quality of medical care-that doctors have ordered tests and other procedures not medically necessary simply to preclude later liability. See Defensive Medicine Hearing, supra note 7, at 166 (statement of Elvoy Raines, Associate Director, Dep't of Professional Liability, American College of Obstetricians and Gynecologists) (expressing the fear that physicians will be selective about the patients they treat and that it may therefore be difficult for some women to find specialists to care for them); id. at 29 (testimony of Arnold J. Rosoff, J.D., Associate Professor, Wharton School of Business, University of Pennsylvania) ("If the system, including the underlying malpractice insurance system, cannot adapt to and support ... changes [in the tort system], severe 
difficult and unlikely to be implemented for many years. Rather than wait for uncertain solutions, midwives should take a lesson from their own history and realize that they may have to solve the current insurance problem on their own. One way the ACNM can achieve this is to self-insure. If feasible, self-insurance will relieve midwives of the difficulty they have faced in obtaining affordable insurance in the commercial market.

\section{A. The Mechanics of Self-Insurance}

There are two alternatives to commercial insurance: to insure captively or to self-insure. Both methods are operated by those who want to be insured; hence, both methods, though distinguished below, will be called "self-insurance."

In a captive insurance arrangement, the association or hospital actually forms and owns its own insurance company. ${ }^{139} \mathrm{~A}$ captive insurer closely resembles a commercial carrier. It collects premiums and maintains a capital fund, but it is limited to providing insurance to its owner group. ${ }^{140} \mathrm{~A}$ number of hospital and physician groups have utilized this method, and many have been successful. ${ }^{141}$

effects on the quality, cost and availability of health care will result.").

${ }^{139}$ See M. Sumner, The Dollars and Sense of Hospital Malpractice INSURANCE 59 (1979). A captive insurance carrier is an "incorporated insurance operation designed to take care of the insurance needs of its parent organization, owner, or sponsor." Id. at 91. "The captive insurer can be organized as a stock company, a mutual, or a reciprocal (that is, an arrangement whereby each insured assumes a proportionate share of every risk being pooled, except its own)." Id. At least one state provides for the formation and licensing of captive insurance companies. See VT. STAT. ANN. tit. $8, \S 141$ (1984). Many have been formed offshore in places such as Bermuda and the Cayman Islands because insurance regulation is minimal under those governments. See M. Sumner, supra, at 61; Jennings, A Tour of Leading Captive Havens, Nat'I Underwriter, Mar. 4, 1983, at 59.

140 See M. SumNer, supra note 139 , at 59 . Some companies have made efforts to diversify into other lines of insurance, because of higher-than-anticipated investment returns and low volume of paid claims. See A Crisis For Do-It-Yourself Malpractice Insurers, Bus. Wk., Apr. 14, 1980, at 66.

141 The Harvard-affiliated medical facilities formed an insurance company in 1976. They reported net savings of three million dollars during their first year. See M. SumNer, supra note 139, at 61 . Some physician-owned companies also have been successful. See Defensive Medicine Hearing, supra note 7, at 133-35 (statement of NORCAL Mutual Insurance Co., a physician-owned, nonprofit insurance company in Northern California) (claiming to have an $85 \%$ success rate in cases litigated and to have kept premium levels stable since 1975 , the pure premium rate having increased by only about 20\%); Rosenberg, Doctor-Owned Malpractice Carriers: Who's Winning, Who's Losing, MED. ECON., Oct. 1, 1984, at 62, 63-64 (stating that three physicianowned companies in California have received an " $A$ " rating from A.M. Best Co., the organization that monitors carrier performance, and that the 2,500-member Physicians Protective Trust Fund in Florida is in its ninth year of successful operations). There have been some failures as well. The Florida Physicians' Insurance Reciprocal, one of 
Under the self-insurance method, ${ }^{142}$ an association or hospital insures itself but does not actually form a separate insurance company. The self-insuring entity expects to absorb losses up to a certain amount and purchases reinsurance to cover losses beyond that amount. ${ }^{143}$ The self-insurer establishes a reserve fund to pay for claims incurred during a year and is free from taxes ${ }^{144}$ and regulations ${ }^{145}$ that apply to other insurance carriers, including captive companies. The ACNM will have to examine the advantages and disadvantages of the two alternatives and determine which will provide the greatest benefit.

\section{B. The Benefits of Self-Insurance}

Both self-insurance and captive insurance systems offer a number of benefits to nurse-midwives. Unlike commercial carriers, a self-insurer is not influenced by a profit-making objective; ${ }^{146}$ if any profits are made, they can be used to accumulate reserves and reduce premiums. In addition, financial savings could be realized with respect to both brokers' fees and administrative costs. ${ }^{147}$

the 10 largest physician-owned companies, has been placed in rehabilitation and is now being managed by the state's insurance department. See id. at 63. The Physicians and Surgeons Insurance Exchange of Los Angeles was declared insolvent, and its assets and obligations have been assumed by a commercial carrier. See id.

142 There is some intellectual controversy over the use of the term "self-insurance." Some commentators argue that since insurance consists of a transfer of risk, selfinsurance is theoretically impossible: one cannot transfer risk to oneself. If self-insurance is defined as a pooling of exposure units, however, the term is accurate. See $H$. Denenberg, R. Eilers, J. Melone \& R. Zeiten, Risk and Insurance 125 (1974) [hereinafter cited as DenENBERG \& EILERS]; E. VAughan, Fundamentals of Risk AND INSURANCE 30 (4th ed. 1986).

143 See M. SuMNER, supra note 139, at 60 . Under self-insurance, "[a]n enterprise such as a hospital retains the malpractice risk up to a level limited by its financial capacity. It appropriates, in advance, reserve funds to meet probable losses. If the funds are insufficient to pay the actual losses, the enterprise must absorb the difference." Id. at 94. Reinsurance transfers coverage of risks from one insurer to another. See DenenBerg \& EIleRs, supra note 142, at 599. It is an ordinary facet of the insurance business and is not peculiar to self-insurance. Id. at 598-600.

144 A self-insurer avoids paying the state premium taxes paid by commercial and captive insurers, which can be as high as five percent in some states. See M. SuMNER, supra note 139, at 60-61. There are, however, tax disadvantages as well. A self-insurer is not allowed income tax credits for loss reserves, and payments to the reserve fund (except for bad debt reserves) are not normally deductible. See id. at 60; DenENBERG \& EILERS, supra note 142, at 130.

${ }^{145}$ The nonregulated status of self-insurers allows them to keep their capital funds smaller than would prove advisable for other carriers. See M. Sumner, supra note 139 , at 60 .

${ }^{148}$ As commentators have noted, "[P]rofitability is the critical, though not the exclusive, factor in [insurance company] decision-making." Roddis \& Stewart, supra note 123, at 1287 (footnote omitted).

147 One of the first known hospital partial self-insurance plans reported a 10 to $20 \%$ savings in brokers' fees and a saving of 40 to $50 \%$ in insurance administrative 
The most important benefit of self-insurance, however, is the potential freedom it offers midwives from the instability of the medical malpractice market. As has been noted, midwives are sued for malpractice relatively infrequently. ${ }^{148}$ This suggests that their premiums have been rising not because of increased negligence on their part or an increase in the number of suits brought against them, but because these events affected the medical profession in general. Consequently, midwives have had to pay for the increase in suits and burgeoning awards against physicians. Self-insurance would eliminate this phenomenon and would allow midwives to pay only for covering the risk of suits brought against members of their own profession. ${ }^{148}$ Since there is little reason to believe that the percentage of suits brought against midwives will increase, ${ }^{150}$ the cost of insuring that risk should not be excessive.

\section{The Feasibility of Self-Insurance}

In determining the feasibility of self-insurance for the ACNM, three elements must be examined: the ACNM's financial capacity to establish an adequate reserve fund; its ability to obtain reinsurance protection for losses that the reserve fund is not equipped to absorb; and the availability of a statistically stable distribution of losses, which is necessary for adequately predicting future losses. ${ }^{151}$

The largest obstacle to overcome is obtaining the initial capital necessary to establish an adequate reserve fund. This fund "must be adequate to assure the policyholder that neither investment nor underwriting losses will prevent a carrier from discharging its obligations." 162 Although the size of the fund would ultimately have to be

costs. See Morris, Medical Report: Malpractice Crisis-A View of Malpractice in the 1970's, 38 INS. Counsel J. 521, 526 (1971). This group did not recommend selfinsurance to others, however. Partial self-insurance involves both keeping reserves against losses and maintaining them for years, "which make[s] the plan of doubtful value" and adds to the "headaches of being forced into the insurance business itself." Id. Other hospitals with self-insurance funds have reported large savings. See M. SumNER, supra note 139 , at 61 .

${ }_{148}$ See supra notes 75-78 and accompanying text.

148 Michael Sumner's analysis of the potential savings of hospital self-insurance supports the conclusion that midwives, under the ACNM aegis, could derive cost savings from self-insurance. Sumner concludes that "[h]ospitals that historically have had better loss experience than most other hospitals may derive cost savings from self-insurance . . . "See M. SUMNER, supra note 139, at 64. Since midwives have "historically had better loss experience" than obstetricians, they should also derive savings from selfinsurance.

${ }^{180}$ See supra notes 75-78 and accompanying text.

161 See M. SumNer, supra note 139 , at $62-63$.

$182 I d$. at 37. Most liability insurers maintain a capital fund with a ratio of one dollar of capital for every three dollars of premium collected. See id. at 85. Some experts argue, however, that it is necessary for malpractice insurers to maintain a lower 
determined by an insurance expert, one can get some idea of what amount is necessary by examining industry standards and applying industry methods. In any event, the size of the capital fund maintained by the ACNM will affect the cost of premiums. If the ACNM wishes to keep premiums relatively low, it will have to establish an adequate capital fund.

In determining the size of the capital fund, the ACNM would likely use the risk-retention method. This method is useful to small carriers that have a large variation in the size of losses and a relatively low incidence of claims. ${ }^{153}$ In calculating a capital fund under this method, "[t]he carrier estimates the maximum number and cost of unexpected claims, and then sets aside into its capital fund monies equal to the total cost. Funds are, therefore, available to pay for unexpected claims without forcing the carrier into bankruptcy."154 If, for example, the ACNM expected to experience ten claims per year and retained a risk of $\$ 50,000$ on each claim, ${ }^{155}$ the minimum size of the capital fund would be $\$ 500,000 .{ }^{156}$

That figure represents only the amount needed for the capital fund and does not include funds needed to pay for administrative costs and the like. Because a large sum of money is necessary for the ACNM to institute a self-insurance system, much thought must be given to possible sources for the necessary funds.

Some physician-owned companies financed their capital funds through loans from policyholders. ${ }^{167}$ Although the ACNM could obtain a portion of the necessary funds in this way, the option is limited because nurse-midwives earn far less and are fewer in number than

ratio of premium-to-capital because of the greater risk involved. Some studies have suggested a ratio between $0.6-$ to-1 and 0.8 -to-1: ten dollars in the capital fund to support six to eight dollars in premiums. Id. at 86.

${ }_{163}$ See id. The low frequency of occurrence precludes the use of more sophisticated methods using probability theory. The risk-retention method is also used to minimize the possibility of insolvency. See id. at 86-87.

164 Id. at 86.

185 Retaining an amount of "risk" on a claim simply means that the primary insurer is liable for that amount on each claim and that the reinsurer is liable for any amount over the amount retained.

${ }_{150}$ Michael Sumner provides a similar example and suggests that a prudent carrier would maintain a fund even larger than that estimated by the risk-retention method in anticipation of the possibility that more than the usual number of claims might occur. See M. SUMNER, supra note 139, at 87.

167 One physician-owned company in New York obtained a loan of $\$ 1,750$ from each policyholder when it began operations. See S. LAw \& S. Pol.AN, supra note 84, at 203. Various medical societies have lent captive companies money as well. See id. at 202. It took NORCAL, a physician-owned, nonprofit insurance company in Northern California founded in 1975 , until 1984 to pay off the loans made to it by policyholders. See Defensive Medicine Hearing, supra note 7, at 135 (statement of NORCAL). 
doctors.

The ACNM could also try to obtain some of the funds from private foundations or to explore the possibility of forming a stock insurance carrier and raising money through the public sale of its stock. ${ }^{168}$ Another option is to look to the federal government for assistance.

One approach the ACNM has used in its effort to obtain insurance has been to ask Congress to establish a federally sponsored program of reinsurance. ${ }^{168}$ The logic behind this tactic is that if private carriers had a readily available source of reinsurance they would be more willing to insure midwives. ${ }^{160}$ Even if this assumption turned out to be correct, however, midwives would remain at the mercy of commercial carriers for primary insurance. Moreover, current skyrocketing federal deficits make it unlikely that Congress will be willing to appropriate the necessary funds.

Rather than asking Congress to get involved in the administration of a reinsurance fund and the large concomitant expense that administering such a program would entail, the ACNM should seek a federally guaranteed loan to capitalize the reserve fund of a self-insurance program. ${ }^{161}$ This option would prove less expensive for the government than sponsorship of a reinsurance fund because funds would be appropriated only to cover a default. Securing a federally guaranteed loan is politically possible: the federal government has a history of bailing out industries and associations in need. ${ }^{\mathbf{1 6 2}}$

The various federal loan guarantee programs "seek to resolve specific socioeconomic problems in order to serve the general wel-

158 According to Karen Ehrnman, Government Relations Coordinator of the ACNM, the organization is currently exploring both of these options. One study on the feasibility of self-insurance, including possible sources of capital, has already been completed, and another has been commissioned. Telephone interview with Karen Ehrnman, ACNM (Nov. 13, 1985).

189 See K. McHugh, supra note 3, at 11.

${ }^{160}$ This conclusion is debatable. Some commentators argue that the unavailability of reinsurance sources is not a significant reason for the primary insurers' refusal to provide coverage. See HEW REPORT, supra note 7, at 547; T. LoMBARDr, supra note 84, at 14.

181 Federal loan guarantees have been used for a number of years to bail out other governments, private enterprises, and individuals, on the grounds that these borrowers would have difficulty obtaining financing at affordable rates without federal assistance and that consequently important socioeconomic interests would go unserved. See Brook \& Cheever, The Federal Loan Guarantee Program: A Unified Approach, $10 \mathrm{~J}$. CoRP: L. 185 (1984). For example, loan guarantees have been given to Chrysler Corp. and New York Gity. See id. at 200.

182 There are currently 170 different federal plans. See id. at 190. These programs include loan guarantees to encourage the development of synthetic fuel research, to provide housing in developing countries, to keep New York City and Chrysler Corp. afloat, to assist consumer cooperatives, and to purchase aircraft. See id. at 228. 
fare . . ."163 General welfare is broadly defined; ${ }^{164}$ assuring the continued existence of the midwifery profession falls into the scope of the term for several reasons, including reduction of the overall cost of health care, care for the poor, and reduction of the number of lowbirth-weight babies, which in turn reduces the infant mortality rate. ${ }^{165}$ Finally, perhaps just as important as financial considerations and benefits to the poor, the existence of midwives is necessary to preserve a woman's right to exercise childbearing choices. ${ }^{166}$ The federal government should respect this right and help to preserve it whenever possible. Congress should therefore be willing to grant the AGNM a federally guaranteed loan.

Once capitalization requirements have been met, the ACNM would have to obtain reinsurance to cover the risks that the reserve fund is not capable of absorbing. This need does not seem to be an insurmountable obstacle. The availability of reinsurance is not considered a major problem in the current malpractice crisis, ${ }^{167}$ and physician-owned companies have succeeded in obtaining it.

The last obstacle the ACNM faces is largely a result of the relatively small number of midwives. This fact, along with the unpredictable nature of malpractice claims in general, may preclude a statistically sound projection of future losses based on the frequency and severity of losses in the past. ${ }^{168}$ The statistical sample of past losses, however, could be expanded by joining with other nurse-practitioner

103 See id. at 199. For example, the federal government has sought to address the following problems through guaranteed loan programs: "the lack of affordable mortgage money for low-income families, the inability of some students to pay the cost of higher education, and the high cost of air pollution control financing for small businesses." Id. at 199 n.109.

164 As commentators have recently pointed out, "[T]here are very few federal programs which actually promote the well-being of all citizens; most programs serve the interest of 'a partial public,' perhaps a very small number of citizens." Id. at 214 (footnote omitted). Midwifery serves more than just a "partial public," however; the majority of women of childbearing age are potential midwife clients.

${ }^{108}$ See supra notes 55-63 and accompanying text.

${ }^{166}$ See supra note 47-54 and accompanying text; Note, Childbearing and NurseMidwives: $A$ Woman's Right to Choose, 58 N.Y.U. L. REv. 661, 682-93 (1983) (arguing that a woman has a constitutional privacy right to make decisions regarding her child's birth).

167 See HEW REPORT, supra note 7, at 547 ("It seems highly doubtful that any established carrier has not entered the malpractice field because of weakness in the reinsurance market."); T. LOMBARDI, supra note 84, at 14 (describing the argument of one reinsurer that reinsurers write only eight to nine percent of the total volume and that "an $8 \%$ tail does not wag a $92 \%$ dog").

168 Past experience is examined in order to predict future losses. DeNENBERG \& EILERS, supra note 142, at 129 . If the statistical base from which prediction is being made is too small, it can affect the mathematical reliability of the results. See Roddis \& Stewart, supra note 123, at 1294. 
groups in a self-insurance program. ${ }^{\mathbf{1 6 9}}$

Although self-insurance is not an ideal solution, it appears to be the only one that the ACNM can hope to accomplish at the present time. If the ACNM takes this approach, it will have to hire insurance experts to study the data and to determine the ultimate feasibility of such a system, and that process will consume time and money. Nevertheless, the alternative of waiting for a solution that will depend on a compromise among the many actors that have a vital interest in this highly intractable problem, including state and federal governments, doctors, lawyers, and the insurance industry, seems to be both naive and unwise.

\section{CONCLUSION}

Midwives provide a valuable service for many members of our society. The continued availability of their services is currently threatened by the cost of medical malpractice insurance.

The problem of the availability and high cost of insurance extends beyond midwives to physicians and other businesses. Although considerable effort has been expended to devise a solution to the overall problem, the causes of the problem are complex and difficult to solve. Therefore, prior attempts at reform have been unsuccessful.

To avoid the ultimate extinction of the midwifery profession due to the lack of malpractice insurance, the ACNM should explore the possibility of self-insurance. Since the preservation of midwifery is in the general welfare, the federal government should help finance the capital fund that the ACNM would need in order to establish a selfinsurance program. Such a program would provide an affordable source of malpractice insurance that is not presently available in the commercial market.

${ }^{168}$ This alternative has been considered by the ACNM. Telephone interview with Karen Ehrnman, Government Relations Coordinator, ACNM (Nov. 13, 1985). Another benefit of such a plan is that a greater amount of the capital fund could be obtained from policyholders and that a smaller loan would be necessary. 